\title{
Technical Study of the Paint Layers from Buddhist Sculptures Unearthed from the Longxing Temple Site in Qingzhou, China
}

\author{
Yan Song ${ }^{1, *}$, Linlin Zhou ${ }^{2}$, Yunpeng Wang ${ }^{3}$, Fangzhi Liu ${ }^{3}$, Juwen Guo ${ }^{1}$, Ruixia Wang ${ }^{2}$ and Austin Nevin ${ }^{4}(\mathbb{D}$ \\ 1 Chinese Academy of Cultural Heritage, Beijing 100029, China; guojuwen@cach.org.cn \\ 2 Qingzhou Museum, Qingzhou 262500, China; qzzhoulin@sohu.com (L.Z.); qzwrx11@163.com (R.W.) \\ 3 Shandong Cultural Relic Conservation and Restoration Center, Jinan 250013, China; \\ husuo8dao008@163.com (Y.W.); lisabac@hotmail.com (F.L.) \\ 4 Courtauld Institute of Art, London WC2R 0RN, UK; austin.nevin@courtauld.ac.uk \\ * Correspondence: songyan@cach.org.cn
}

Citation: Song, Y.; Zhou, L.; Wang, Y.; Liu, F.; Guo, J.; Wang, R.; Nevin, A Technical Study of the Paint Layers from Buddhist Sculptures Unearthed from the Longxing Temple Site in Qingzhou, China. Heritage 2021, 4, 2599-2622. https://doi.org/10.3390/ heritage 4040147

Received: 25 August 2021

Accepted: 18 September 2021

Published: 22 September 2021

Publisher's Note: MDPI stays neutral with regard to jurisdictional claims in published maps and institutional affiliations.

Copyright: (c) 2021 by the authors. Licensee MDPI, Basel, Switzerland. This article is an open access article distributed under the terms and conditions of the Creative Commons Attribution (CC BY) license (https:// creativecommons.org/licenses/by/ $4.0 /)$.

\begin{abstract}
In 1996, more than four hundred Buddhist statues were excavated from the Hoard of Longxing Temple site in Qingzhou, Shandong Province, China. They are of great significance in the study of Buddhism history during the Northern and Southern Dynasties of China, and have attracted widespread attention since they were unearthed. In this paper, the paint layers from 14 of the Buddhist statues unearthed from the Longxing Temple site were analyzed using portable 3D microscopy, Raman spectroscopy and X-ray fluorescence spectroscopy was used to determine the materials used in their production. Several microscopic samples were analyzed in the laboratory using scanning electron microscopy/energy dispersive spectrometer, X-ray diffraction and microRaman spectroscopy. The combined results from the field and laboratory analyses materials used in painting layers of these statues were identified, and the technique for the production of the sculptures was studied. After the stone sculpture of Buddha was finished, a priming layer of lead white was applied over the stone body as a ground, over which pigments were applied. These include mineral pigments (cinnabar, malachite, lapis lazuli and cerussite), Chinese ink (carbon black) and gold leaf. Cinnabar was used for the outer garments, the halos and ornaments of Buddha and Bodhisattva statues; malachite, was found primarily on the Monk's clothing; the blue pigment, lapis lazuli, was mainly used for the Buddha's bun, halo and outer garment edges; carbon black ink was employed for drafting and sketching clothing and decorative patterns.
\end{abstract}

Keywords: Qingzhou; Longxing Temple; Buddhist statues; color painting; gliding; Northern and Southern Dynasty

\section{Introduction}

As a city name, Qingzhou appeared in ancient times. It is located in the middle area of Shandong Peninsula and used to be a political, economic, military and cultural capital, and the Buddhist Center of the Shandong area.

During the Northern Wei and Eastern Wei dynasties, Buddhism developed rapidly and reached its peak in the Northern Qi Dynasty. As one of the important birthplaces and the third largest city of the Northern Qi Dynasty, Buddhism development in Qingzhou also reached its peak. The prosperity of Buddhism has left many Buddhist relics in Qingzhou. In recent decades, many Buddhist statues have been unearthed in the Qingzhou area, of which the most influential are the Buddhist statues unearthed from the Longxing Temple site. In October 1996, archaeologists from the Qingzhou Museum excavated a large hoard of over 400 Buddhist statues in the north of the Longxing Temple site. According to the inscription on some statues, the dating of the statues is from the Northern Wei Dynasty to Northern Song Dynasties (529-1026 C.E.). These statues are rare in Buddhist archaeology because of their large number, complete variety, the long temporal duration of the burial site, fine carving technique, and well-preserved color painting and gilding [1,2]. For these 
reasons, the statues have gained extensive attention and have been the subject of major international exhibitions [3].

The style of Qingzhou statues is significantly different from that of other famous Buddhist sites, including the Mogao Grottoes, Longmen Grottoes and the Yungang Grottoes. By continuous exploration and integration of different cultural characteristics, craftsmen in Qingzhou developed many new breakthroughs in carving techniques and artistic styles, especially the Buddhist statues unearthed from Longxing Temple site, which have been ascribed a specific "Qingzhou style" by some experts $[4,5]$. They have been suggested to embody the Buddhist regulations and local characteristics of the Qingzhou area during the Northern Dynasty. Despite the damage to the integrity of most sculptures, with many works missing heads and limbs, the paint layers and gilding of most statues are relatively well preserved and provides unique data for the study of ancient practice [6]. Since the statues were unearthed, many scholars have conducted in-depth research on the sculptures, which has mostly focused on the history, art, style, shape, dress adornment and decorative pattern [7-19].

However, compared with the studies on history, art, culture and other fields, technical studies of the painting materials and the production of Buddhist statues from Longxing Temple site are relatively limited. The purpose of this work is to investigate the materials used for the production of the sculptures, and to identify the distribution of pigments in specific areas of the sculptures. Analytical results were combined to identify the raw materials and technological trends in the production of selected Buddhist statues from the Longxing Temple in Qingzhou. After excavation, the statues have been restored and most cannot be sampled. In parallel, technological advances have improved the capabilities of analytical instrumentation for in situ analysis. This paper focuses on the application of in situ analysis based on a combination of X-ray fluorescence, Raman spectroscopy and optical microscopy to the study of the pigments and materials found on works, and is complemented by limited sampling from loose fragments of one sculpture.

\section{Materials and Methods}

\subsection{Information about the Statues Selected}

Fourteen Buddhist statues (two in Eastern Wei, one in Eastern Wei-North Qi and eleven in the Northern Qi Dynasty) are selected for study. A summary of their information is shown in Table 1.

Table 1. Information about the Buddhist statues investigated in this study.

\begin{tabular}{|c|c|c|}
\hline Statue ID & Dynasty & Description \\
\hline L0005 & $\begin{array}{l}\text { Eastern Wei } \\
\text { (536 C.E.) }\end{array}$ & $\begin{array}{l}\text { A high relief sculpture made of limestone with one Buddha and two } \\
\text { Bodhisattvas. Two sitting Buddha are remained on the upper part of back } \\
\text { screen, and four painted monks are reserved on both sides. The remnant } \\
\text { height is } 83 \mathrm{~cm} \text {. }\end{array}$ \\
\hline L0144 & $\begin{array}{l}\text { Northern Qi } \\
\text { (550-577 C.E.) }\end{array}$ & $\begin{array}{l}\text { A gilded and painted statue of Buddha made of limestone, } 138 \mathrm{~cm} \text { high. } \\
\text { The statue is dressed in a black cassock with right shoulder exposed, } \\
\text { standing barefoot on a lotus throne. Buddha in a black cassock is rare. }\end{array}$ \\
\hline L0190 & $\begin{array}{l}\text { Northern Qi } \\
\text { (550-577 C.E.) }\end{array}$ & $\begin{array}{l}\text { A round-sculpture of Buddha made of limestone. } 57.7 \mathrm{~cm} \text { high, } 24.1 \mathrm{~cm} \\
\text { wide and } 14.8 \mathrm{~cm} \text { thick. It is tall and straight with whole body painted and } \\
\text { gilded, but head and both hands and feet. Are missing. }\end{array}$ \\
\hline L0233 & $\begin{array}{l}\text { Northern Qi } \\
\text { (550-577 C.E.) }\end{array}$ & $\begin{array}{l}\text { A round-sculpture of Buddha made of white marble, with clothes tightly } \\
\text { adhering to the body. } 71.9 \mathrm{~cm} \text { high, } 27.9 \mathrm{~cm} \text { wide and } 17.7 \mathrm{~cm} \text { thick. Head } \\
\text { and limbs are missing. }\end{array}$ \\
\hline L0617 & $\begin{array}{l}\text { Eastern Wei- Northern Qi } \\
\quad \text { (534-577 C.E.) }\end{array}$ & $\begin{array}{c}\text { Only the lower part of the body and drapery remains. } 26.5 \mathrm{~cm} \text { high, } 19 \mathrm{~cm} \\
\text { wide and } 9.8 \mathrm{~cm} \text { thick. Its cassock is carved with double intaglio lines and } \\
\text { painted. Some areas are blackened. }\end{array}$ \\
\hline
\end{tabular}


Table 1. Cont.

\begin{tabular}{|c|c|c|}
\hline Statue ID & Dynasty & Description \\
\hline L0307 & $\begin{array}{l}\text { Northern Qi } \\
\text { (550-577 C.E.) }\end{array}$ & $\begin{array}{l}\text { A round sculpture made of limestone with remnant height of } 150 \mathrm{~cm} \text {. The } \\
\text { Buddha is dressed in a round collar cassock with red background. } \\
\text { Buddhist imagery is depicted on the front and back of the cassock. The } \\
\text { gold layer is well preserved. }\end{array}$ \\
\hline L0196 & $\begin{array}{l}\text { Northern Qi } \\
\text { (550-577 C.E.) }\end{array}$ & $\begin{array}{l}\text { A round-sculpture of Buddha made of limestone. } 51.6 \mathrm{~cm} \text { high, } 24.3 \mathrm{~cm} \\
\text { wide and } 13.2 \mathrm{~cm} \text { thick. Head, left finger, right arm and feet are missing. }\end{array}$ \\
\hline L0203 & $\begin{array}{l}\text { Northern Qi } \\
\text { (550-577 C.E.) }\end{array}$ & $\begin{array}{l}\text { A round-sculpture of Buddha made of limestone. } 43.1 \mathrm{~cm} \text { high, } 16.2 \mathrm{~cm} \\
\text { wide and } 13.7 \mathrm{~cm} \text { thick. Head, left finger, right arm and feet are missing. }\end{array}$ \\
\hline L0204 & $\begin{array}{l}\text { Eastern Wei } \\
(534-550 \text { C.E. })\end{array}$ & $\begin{array}{l}\text { A round-sculpture of Buddha made of limestone. } 64.1 \mathrm{~cm} \text { high, } 21 \mathrm{~cm} \text { wide } \\
\text { and } 13.9 \mathrm{~cm} \text { thick. Head and hands are missing. There are mat marks on } \\
\text { the chest and a lot of crusts on the back. }\end{array}$ \\
\hline L0212 & $\begin{array}{l}\text { Northern Qi } \\
\text { (550-577 C.E.) }\end{array}$ & $\begin{array}{l}\text { A round-sculpture of Buddha made of limestone } .56 .8 \mathrm{~cm} \text { high, } 23.8 \mathrm{~cm} \\
\text { wide and } 15.1 \mathrm{~cm} \text { thick. The head, right arm and feet are missing. }\end{array}$ \\
\hline L0219 & $\begin{array}{l}\text { Northern Qi } \\
\text { (550-577 C.E.) }\end{array}$ & $\begin{array}{c}\text { A round-sculpture of Buddha made of limestone. } 52.3 \mathrm{~cm} \text { high, } 22.2 \mathrm{~cm} \\
\text { wide and } 13 \mathrm{~cm} \text { thick. Head, left hand, right arm and feet are missing. } \\
\text { There are multi-layer paintings on the cassock. }\end{array}$ \\
\hline L0227 & $\begin{array}{l}\text { Northern Qi } \\
\text { (550-577 C.E.) }\end{array}$ & $\begin{array}{l}\text { A round-sculpture of Buddha made of limestone. } 58.3 \mathrm{~cm} \text { high, } 24.3 \mathrm{~cm} \\
\text { wide and } 14.2 \mathrm{~cm} \text { thick. Head and limbs are missing. There are mat marks } \\
\text { on the abdomen. }\end{array}$ \\
\hline L0229 & $\begin{array}{l}\text { Northern Qi } \\
\text { (550-577 C.E.) }\end{array}$ & $\begin{array}{l}\text { A round-sculpture of Buddha made of limestone. } 63.3 \mathrm{~cm} \text { high, } 21.9 \mathrm{~cm} \\
\text { wide and } 13.2 \mathrm{~cm} \text { thick. Head and limbs are missing. }\end{array}$ \\
\hline L0230 & $\begin{array}{l}\text { Northern Qi } \\
\text { (550-577 C.E.) }\end{array}$ & $\begin{array}{l}\text { A round-sculpture of Buddha made of limestone. } 66.9 \mathrm{~cm} \text { high, } 25.5 \mathrm{~cm} \\
\text { wide and } 17.5 \mathrm{~cm} \text { thick. Head, left hand and feet are missing. }\end{array}$ \\
\hline
\end{tabular}

Images of the most representative statues are shown in Figures 1-6; details on the other works investigated are provided in the Appendix A: High-Definition Images of 8 Statues (Figure A1, Figure A2, Figure A3, Figure A4, Figure A5, Figure A6, Figure A7, Figure A8). These images illustrate the range in condition and polychromy of the sculptures studied as well as the common loss of limbs and heads in many of the works.

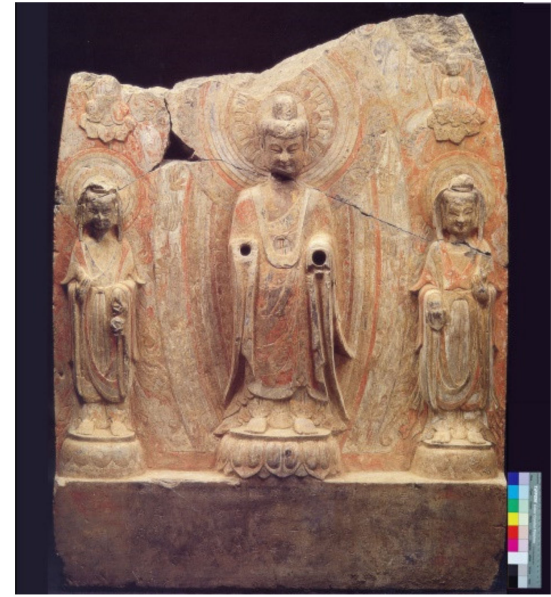

(a)

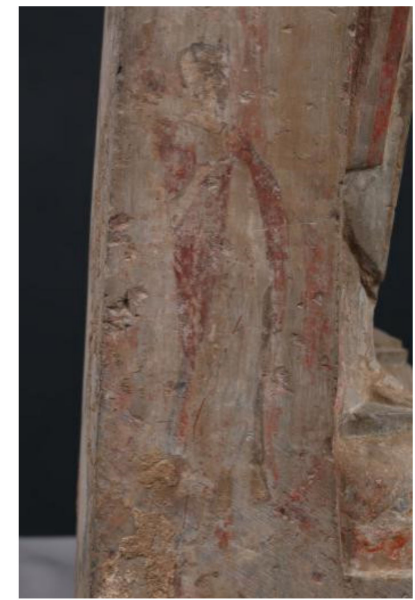

(b)

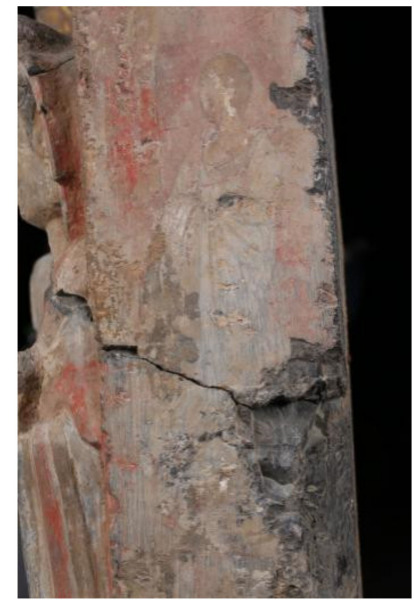

(c)

Figure 1. Overall (a) and detailed (b,c) images of the polychromy of the L0005. See Table 1 for description. 


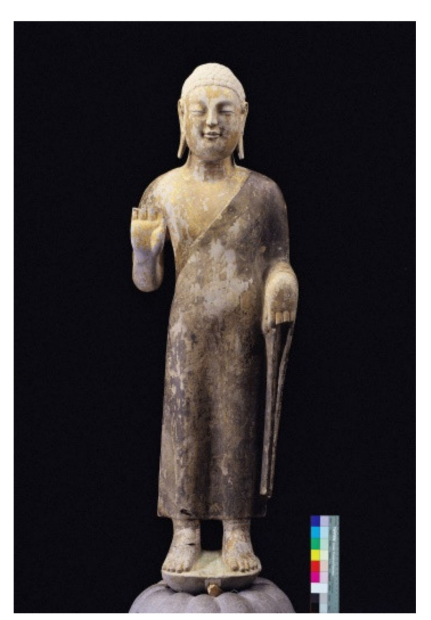

Figure 2. Front of the L0144.

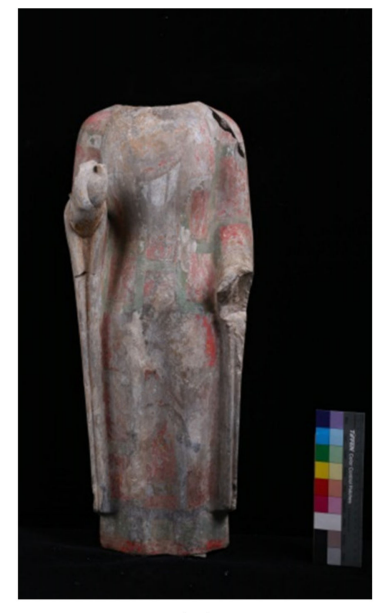

(a)

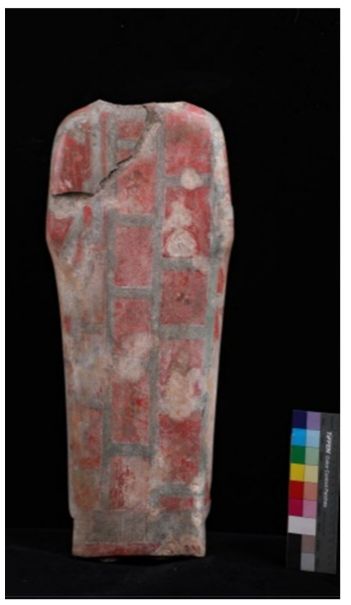

(b)

Figure 3. Front (a) and back (b) of L0190.

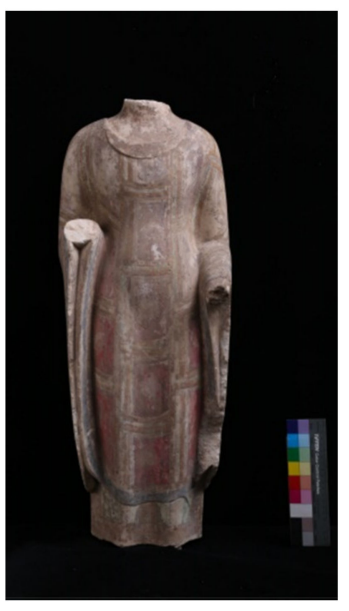

(a)

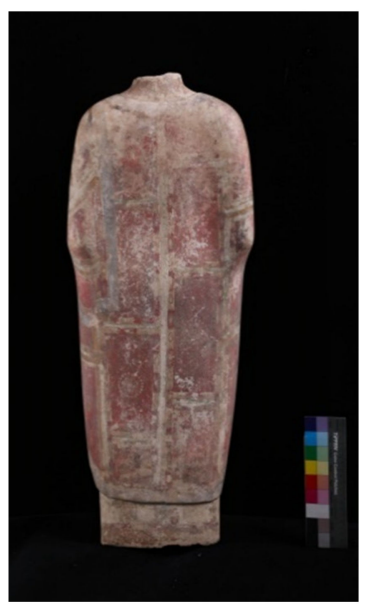

(b)

Figure 4. Front (a) and back (b) of L0233. 


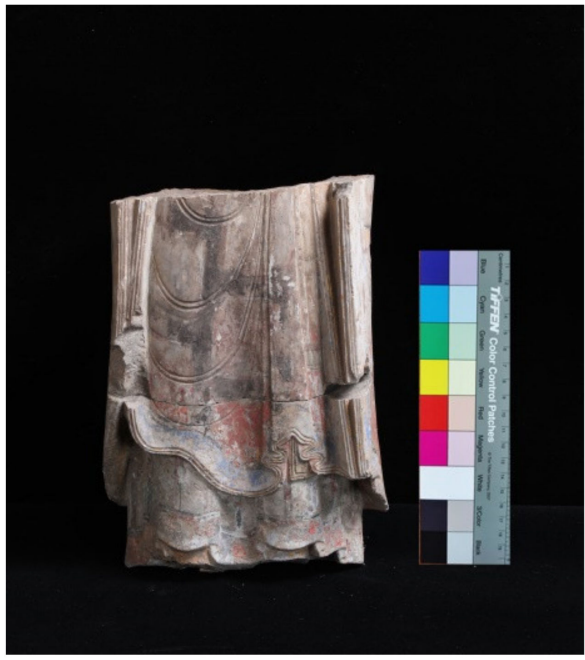

(a)

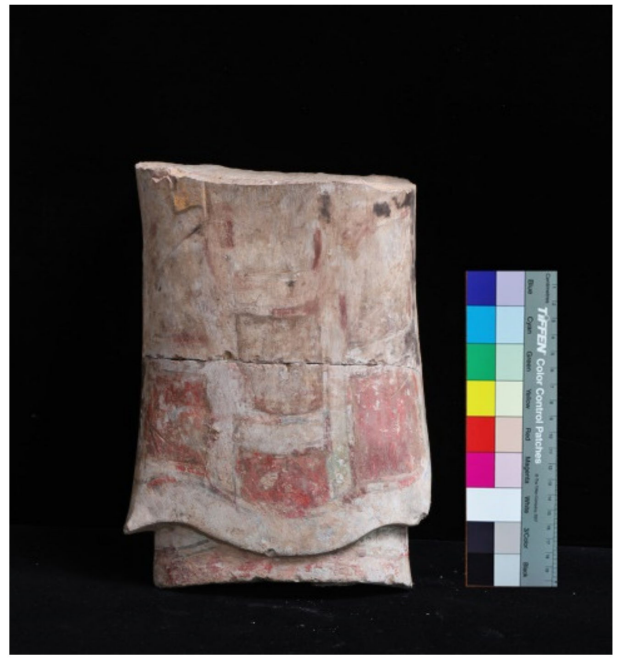

(b)

Figure 5. Front (a) and back (b) of L0617.

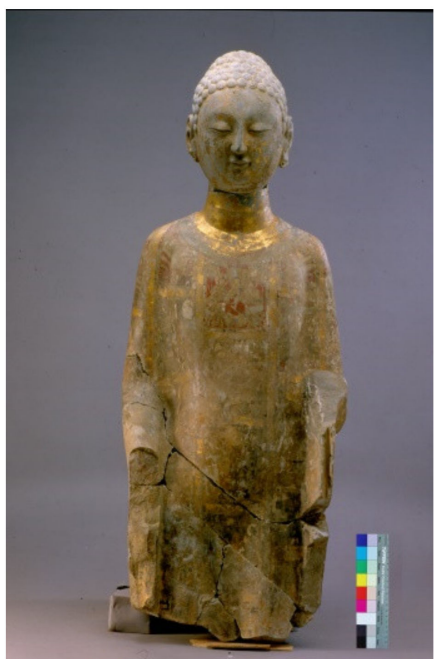

(a)

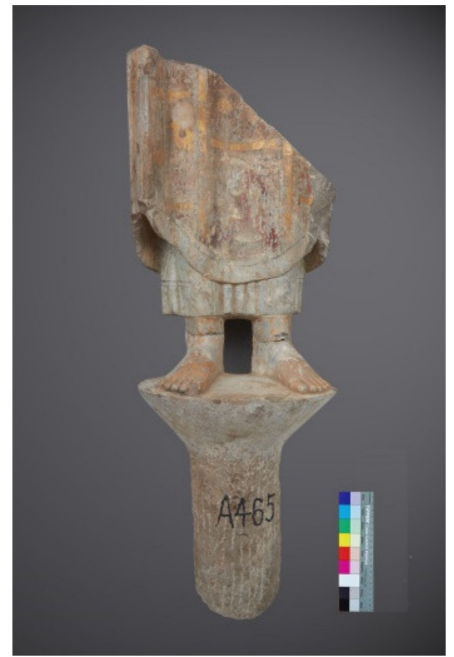

(b)

Figure 6. Upper (a) and lower parts (b) of L0307.

\subsection{Analytical Methods}

In situ analysis was carried out with portable instrumentation.

A HIROX RH-2000 portable 3D video microscope equipped with a hand-held zoom lens (with ACS function), magnification 20-160×, working distance $44 \mathrm{~mm}$, observation range 15.4-2.0 $\mathrm{mm} \mathrm{(h),} \mathrm{and} \mathrm{depth} \mathrm{of} \mathrm{field} \mathrm{13.3-0.25} \mathrm{mm} \mathrm{was} \mathrm{employed} \mathrm{for} \mathrm{microscopic}$ documentation of the paint layers in the statues.

X-ray fluorescence was carried out using the Tracer 3 portable X-ray fluorescence spectrometer (Bruker) equipped with a micro ceramic X-ray tube (Rh target), using the following conditions: maximum excitation voltage $45 \mathrm{kV}$, maximum current $45 \mu \mathrm{A}$, energy resolution of $145 \mathrm{eV}$, with $16 \mathrm{~s}$ measuring time per sample, with spectral resolution of $20 \mathrm{eV}$.

A portable Raman spectrometer supplied by HORIBA HE equipped with white lighting system, high resolution color camera, $50 \times$ telephoto lens, holographic concave grating, $3^{*}$ TE cooled CCD detector, pixel size $26 \mu \mathrm{m}$, spectral range $100-3200 \mathrm{~cm}^{-1}$, spectral resolution $\leq 3 \mathrm{~cm}^{-1}$, equipped with three lasers $532 / 633 / 785 \mathrm{~nm}$, laser power is $80-300 \mathrm{mw}$ and above (the power is adjustable).

Laboratory analysis was carried out with X-ray diffraction, scanning electron microscope/energy dispersive spectrometer and Raman spectroscopy. 
A Phenom XL scanning electron microscope/energy dispersive spectrometer (FEI, The Netherlands) with $15 \mathrm{kV}$ voltage and matching current were used to collect data on each sample, with measurement time of $30 \mathrm{~s}$.

X-ray diffraction was recorded on micro-samples with an Aeris table X-ray diffractometer (PANalytical, The Netherlands): The maximum output power of an X-ray emitter is $600 \mathrm{~W}$, tube voltages and current is set to $40 \mathrm{kV}$ and $15 \mathrm{~mA}$ respectively, with a target

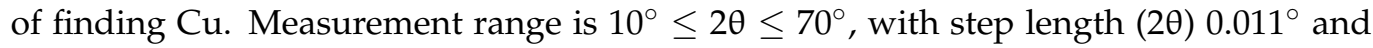
scanning time $48 \mathrm{~s}$ per step.

An inVia reflex Raman confocal spectrometer (Renishaw, New Mills, UK) with a $532 \mathrm{~nm}$ laser, operating at $5 \%$ power over a spectral range $100-3500 \mathrm{~cm}^{-1}$, with scanning time $10 \mathrm{~s}$ and 10 accumulations was employed. Analysis of pigments using Raman spectroscopy is based on the comparison with published database, the RRUFF database and Sadtler standard spectra.

\section{Results and Discussion}

\subsection{Analysis of Materials}

On the 13 Buddhist statues (L0307 was not tested by XRF because of problems with access), 97 points for analyses were selected, and the elemental composition was determined by portable XRF. The results (see Appendix B: Table A1. Results of the in-situ XRF analysis carried on the 13 Buddhist statues investigated in this study) show that: (1) red zones generally contained $\mathrm{Hg}$ and $\mathrm{S}$, suggesting the presence of $\mathrm{HgS}$; (2) green zones generally contained $\mathrm{Cu}$, suggesting the presence of a $\mathrm{Cu}$-containing pigment, such as malachite; (3) white zones generally contained $\mathrm{Pb}$, suggesting the presence of a $\mathrm{Pb}$-containing mineral, which was present in most XRF analysis, suggesting that $\mathrm{Pb}$ is found in the ground layer; (4) gilding zones generally contained $\mathrm{Au}$ and $\mathrm{Pb}$, suggesting the presence of gold and a lead-based priming layer beneath the gilding. In addition to the above chromogenic elements, other elements (such as the major signal from $\mathrm{Ca}$, or trace elements $\mathrm{Fe}$, $\mathrm{Ti}$ and $\mathrm{Si}$ ) may come from the rock body (limestone and white marble) or the soil crust that is present as residual dirt on the surface of statue. The presence of Fe suggested that earth pigments could be present in the paint.

In order to determine the molecular composition of pigments and confirm the identification of pigments inferred with elemental analysis, a portable Raman spectrometer was used for the analysis of selected areas from the sculptures. However, due to the luminescence, likely from organic materials used during restoration, binding media and impurities that contribute to fluorescence, definitive results were only obtained on red and black pigments of the two works. Carbon black was identified in some black lines in the lower part of the right frock of L0307 (Figure 7) via the characteristic bands seen at 1370 and $1598 \mathrm{~cm}^{-1}$. The band at $173 \mathrm{~cm}^{-1}$ has not been identified and could be related to an artefact in the instrumentation. Considering that carbon black is the main component of Chinese ink, and the morphology of the black brush strokes, the black pigment could have been Chinese ink. As suggested by signal from $\mathrm{Hg}$ and $\mathrm{S}$ with XRF, Raman confirmed the presence of cinnabar in the red area of the front skirt of L0307 (Figure 8), which was confirmed via comparison with reference databases and the characteristic bands at 249 and $347 \mathrm{~cm}^{-1}$. In addition to L0307, cinnabar was also found on the right upper arm and shoulder of L0190 (Figure 9). 


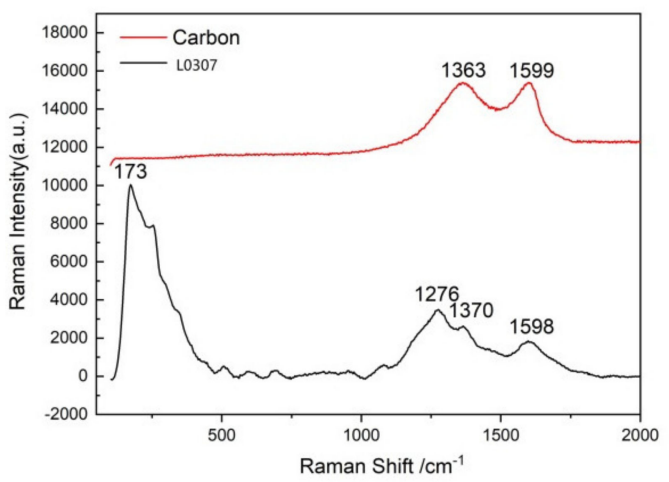

Figure 7. Raman spectrum of black lines in the lower part skirt of L0307 statue (C).

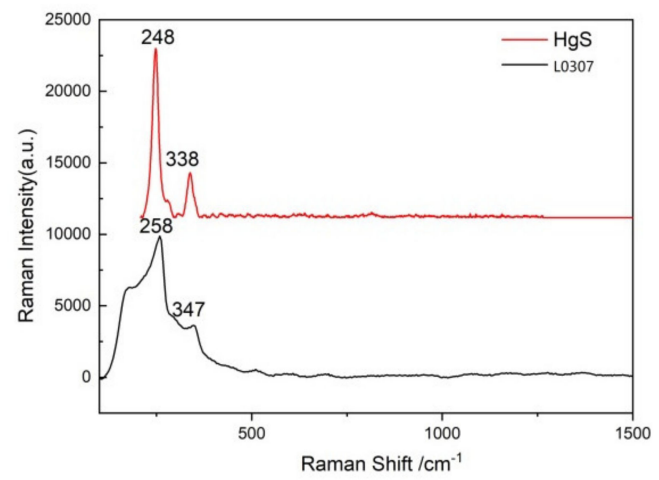

Figure 8. Raman spectrum of red pigment at bottom of skirt of L0307 statue (HgS).

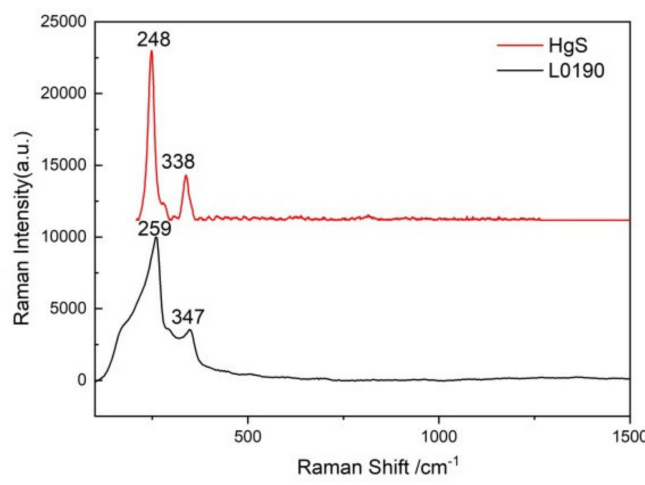

(a)

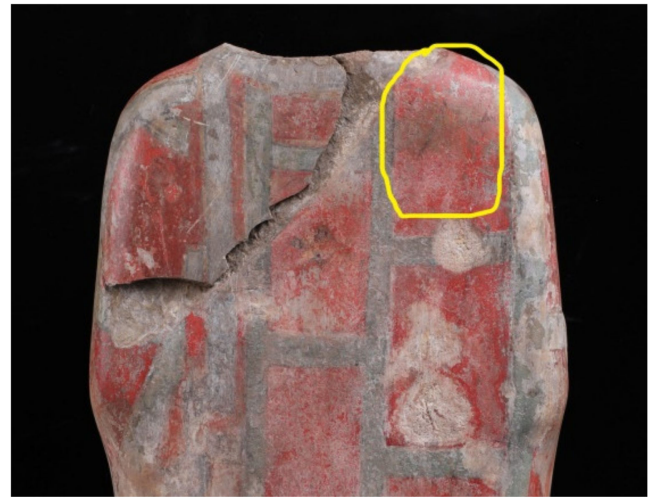

(b)

Figure 9. Raman spectrum of the red pigment on the right shoulder of L0190 statue (a) and the location of analysis (b).

For additional confirmation of pigment composition and the analysis of micro-samples that were available from only one statue, laboratory analysis using XRD and Raman spectroscopy was carried out. XRD was applied to analyze red, green, blue and white pigment samples collected from L0617. The results confirmed the red pigment to be cinnabar (Figure 10), the green as malachite (Figure 11) and the white as lead white (Figure 12). Trace signal from quartz and other silicates was found mixed with the pigments and ascribed to the burial material. The blue pigment was not identified by XRD. Instead, SEM-EDX analysis of the blue sample (Figure 13) showed the concentrations (Wt\%) of $\mathrm{Si}(24.0 \%), \mathrm{Ca}(14.6 \%), \mathrm{Al}(11.2 \%)$ and $\mathrm{Na}(8.4 \%)$ to be high with a chemical composition consistent with ultramarine, and confirms that the blue sample does not contain $\mathrm{Cu}$. Using micro-Raman spectroscopy in the laboratory, it was possible to confirm ultramarine from 
the blue sample (Figure 14). Bands identified at 261, 549 and $1095 \mathrm{~cm}^{-1}$ are characteristic of the pigment extracted from lapis lazuli [20].

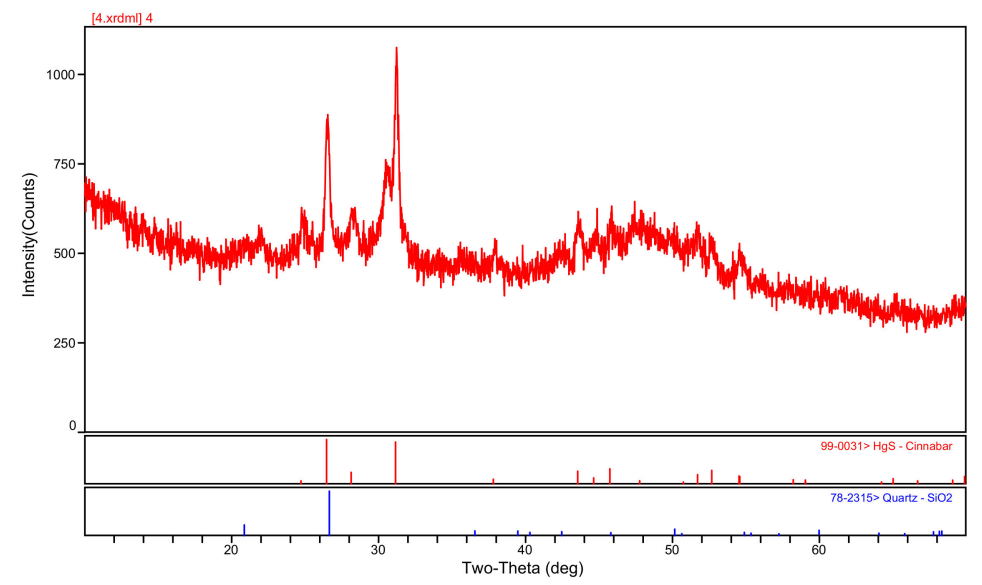

Figure 10. XRD spectrum of cinnabar from L0617.

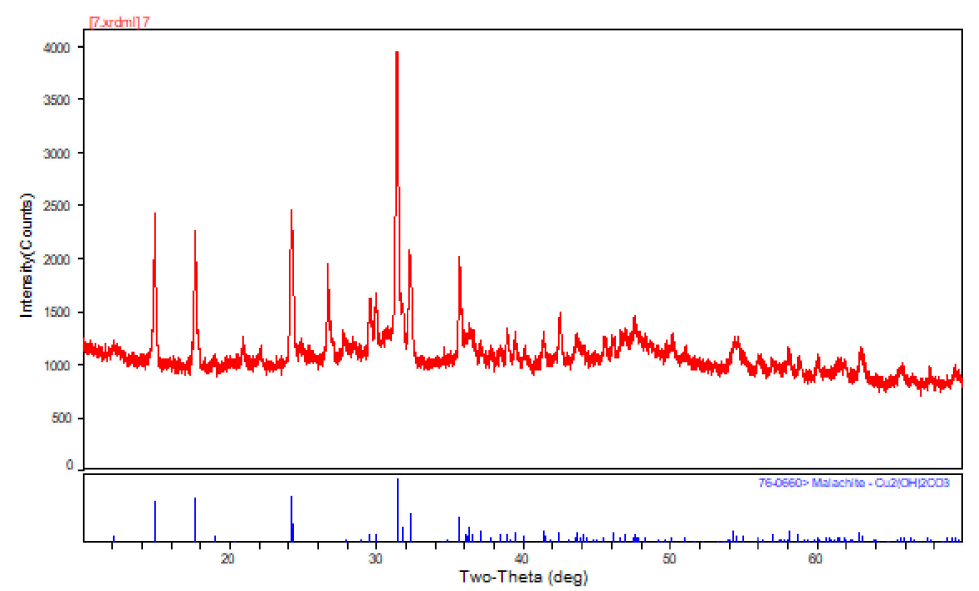

Figure 11. XRD spectrum of malachite from L0617.

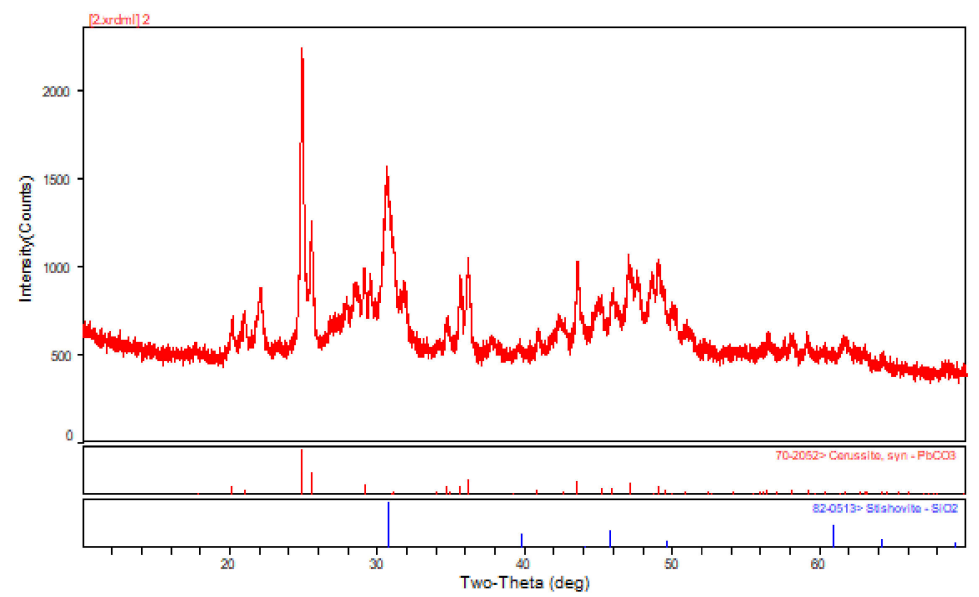

Figure 12. XRD spectrum of lead white from L0617. 


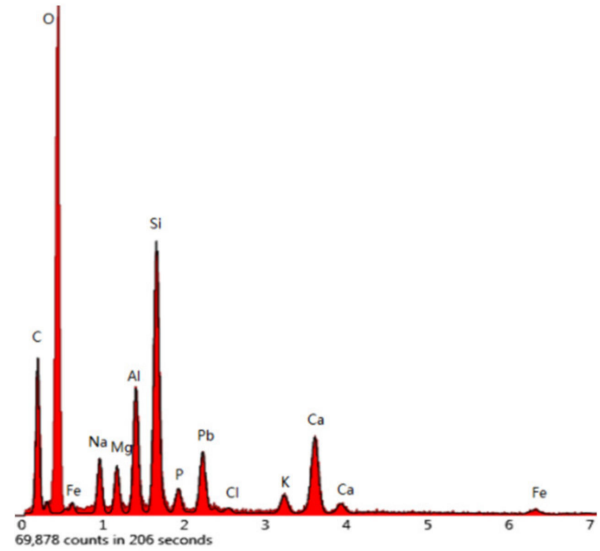

(a)

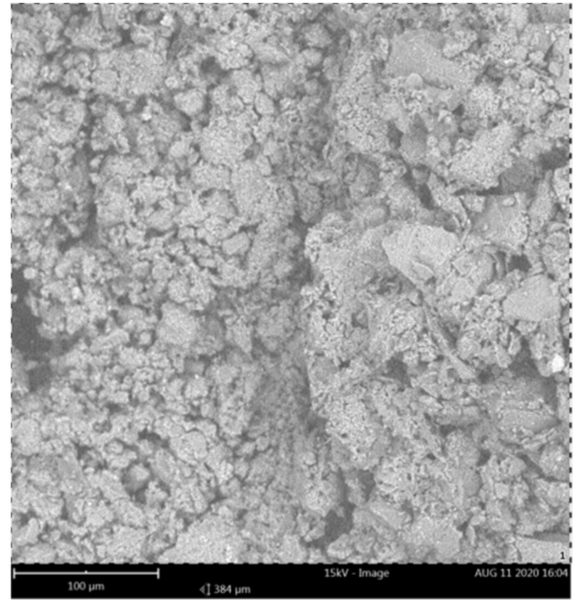

(b)

Figure 13. SEM/EDX analysis (a) and BSE image of an area shown in (b) of blue pigment from statue L0617.

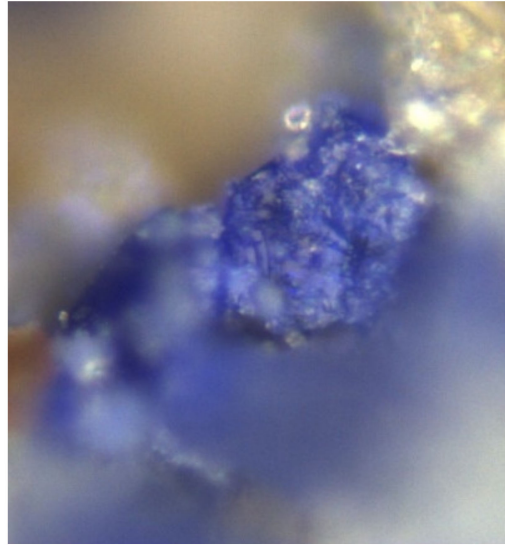

(a)

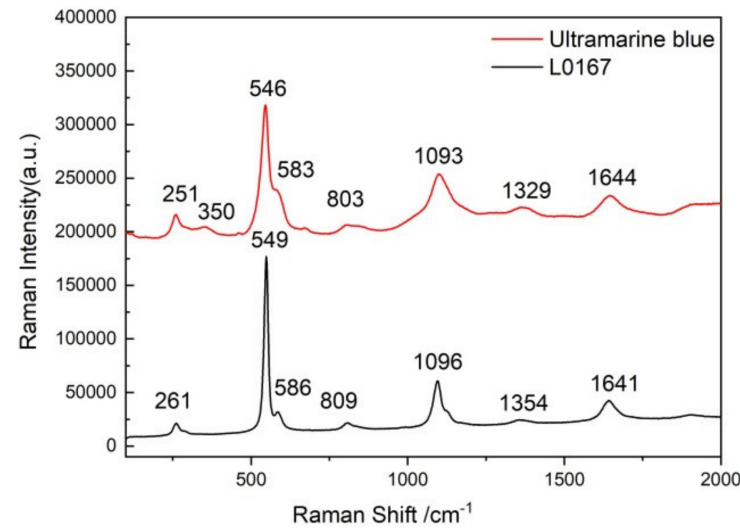

(b)

Figure 14. Test area (a) and Raman spectrum (b) of the blue pigment on L0617 statue (The Raman spectrum acquired from a sample is compared with a spectrum of a reference sample of ultramarine blue).

Based on analysis described above, no Fe-containing pigments were identified and instead the pigments used in these Buddhist sculptures were as follows: the red pigment as cinnabar $(\mathrm{HgS})$, the green pigment as malachite $\left[\mathrm{CuCO}_{3} \cdot \mathrm{Cu}(\mathrm{OH})_{2}\right]$, the blue pigment as lapis lazuli $\left(\mathrm{Na}_{6} \mathrm{Al}_{4} \mathrm{Si}_{6} \mathrm{~S}_{4} \mathrm{O}_{20}\right)$, the white foundation layer as cerussite $\left(\mathrm{PbCO}_{3}\right)$, and the gilding material as gold leaf. No silver was detected in the works. This is consistent with the results reported in the literature for similar objects [21-23].

\subsection{General Description of Paint Application and Gilding}

With the help of a portable microscope, the micro morphology of the painted layer of 14 statues was observed, which is fundamental for the understanding of the stratigraphy and the identification of painting and gilding techniques. Figures 15-20 are some representative micrographs of paint layers and gilding. 


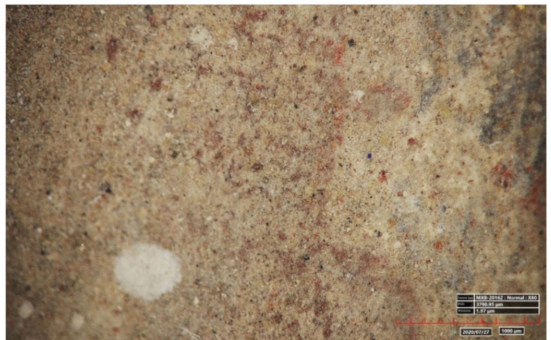

(a) Residual red pigment on the left knee of L0204

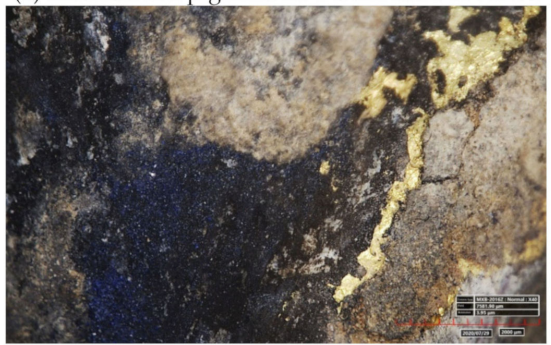

(c) Residual blue pigment on the Buddha bun of L0005

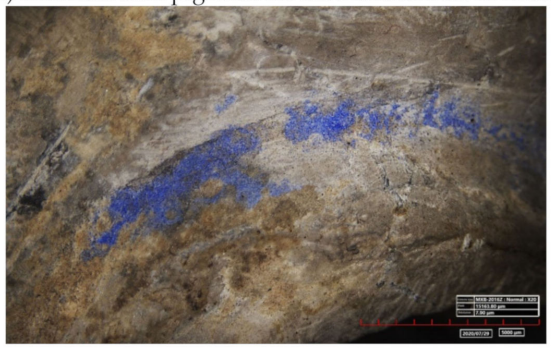

(e) Residual blue pigment on the left sleeve edge of Buddha of L0005

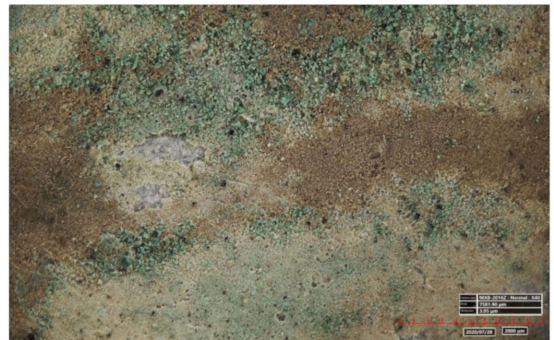

(b) Residual blue pigment on the Buddha bun of L0144

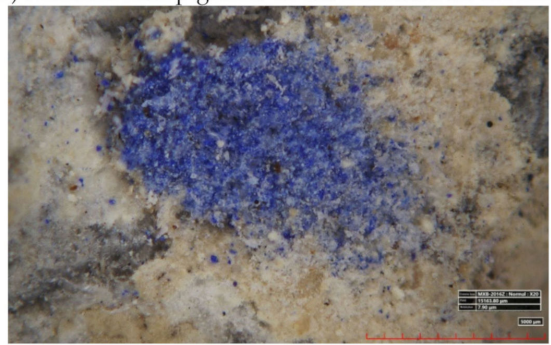

(d) Residual blue pigment on the Buddha bun of L0144

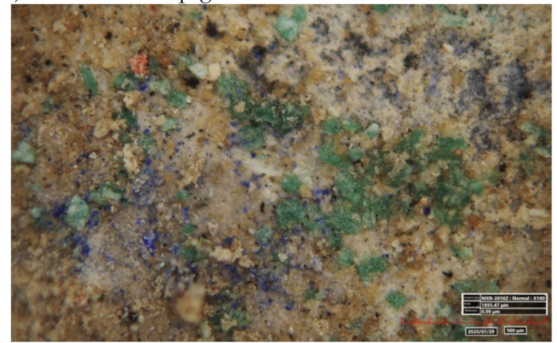

(f) Residual blue and green pigments on the hola of Buddha of L0005

Figure 15. Residue of red, green and blue pigments showing variation in the concentration of trace pigments in some cases (a-f), layering of blue over black (c) to the distribution and pigment mixtures (for example green, blue and black (f).

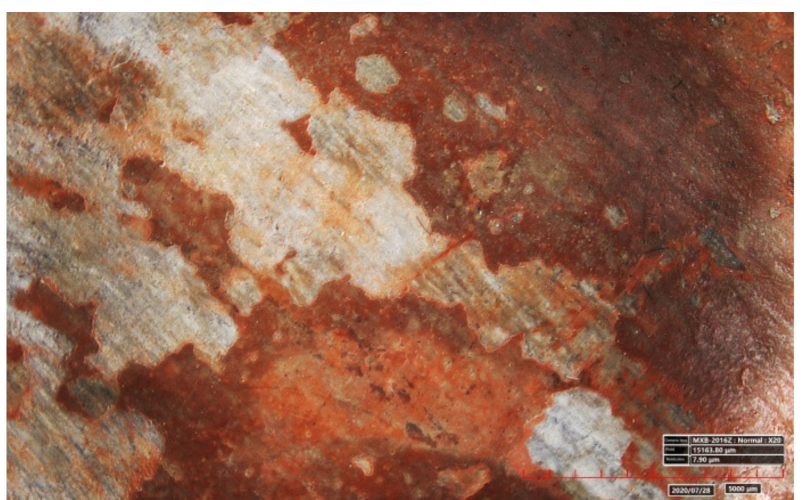

(a)

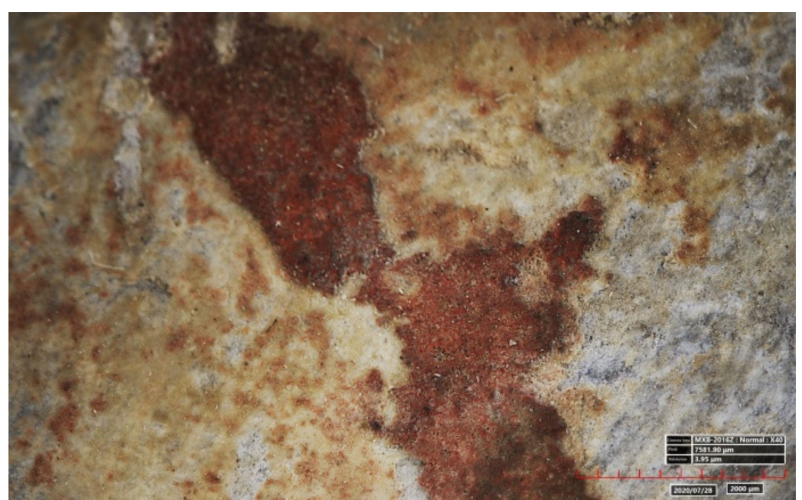

(b)

Figure 16. The relationship between the pigment layer and the underlying preparation layer on the statue. (a) On the left, marks related to the application of a foundation with a brush are seen. (b) On the right, areas of the foundation have been abraded to reveal the underlying grey stone. 


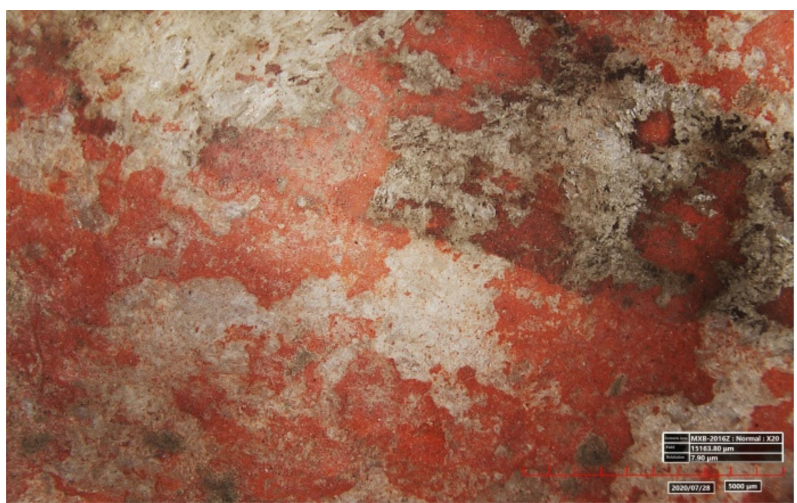

(a)

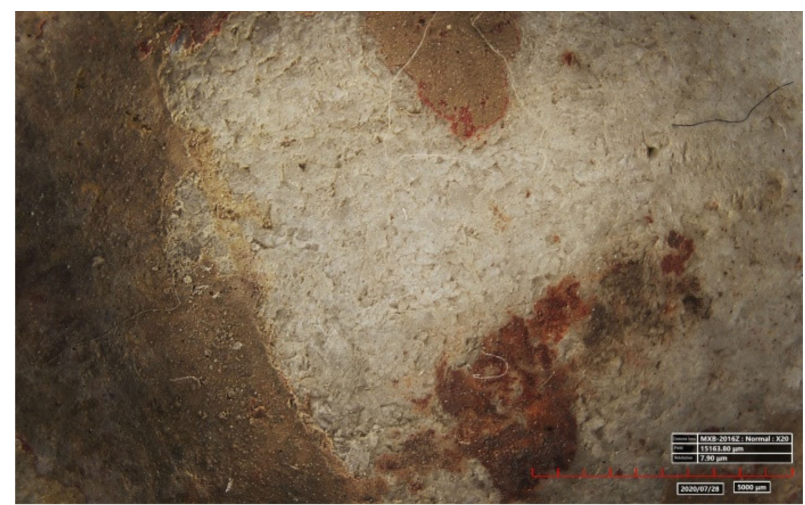

(b)

Figure 17. Pigment is painted directly on the stone surface on L0233 in multiple layers (a) without the presence of the lead white ground. Areas of loss reveal the smoothly polished white stone surface (b).

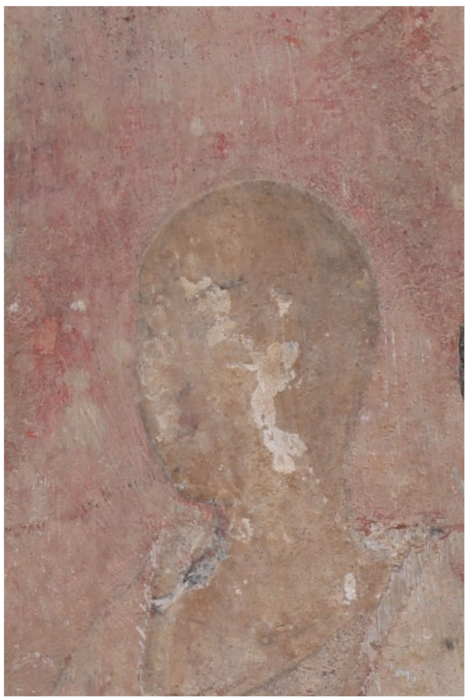

(a)

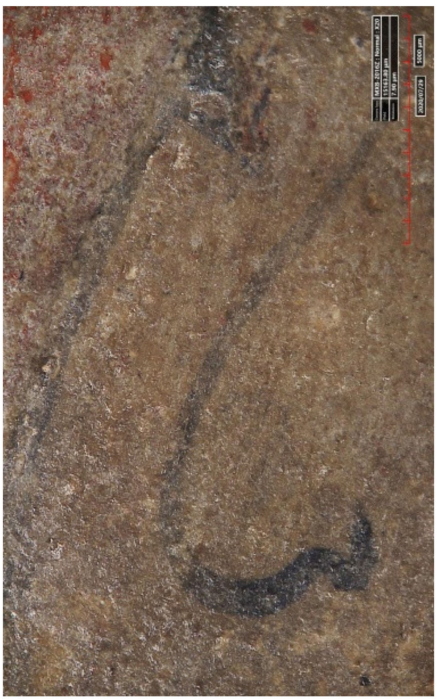

(b)

Figure 18. On the left side of the back screen of L0005, facial features of a young monk are painted with Chinese ink ((a) is the entire face of the monk; $(\mathbf{b})$ is the enlarged outline of his nose).

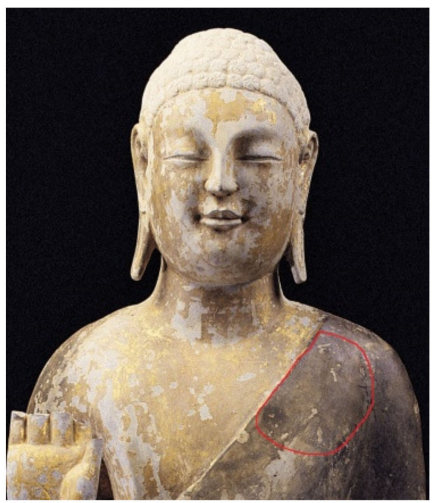

(a)

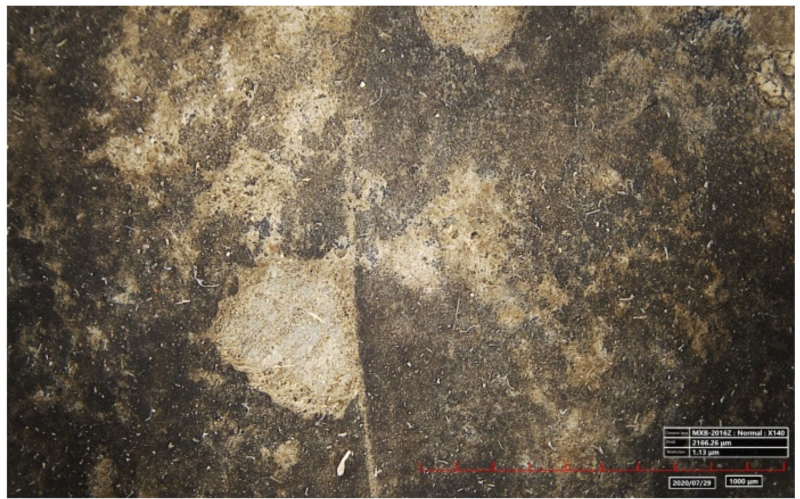

(b)

Figure 19. Image of the thin black paint on the neckline of L0144 outlined in red (a) and macro image of the black cassock (b). 

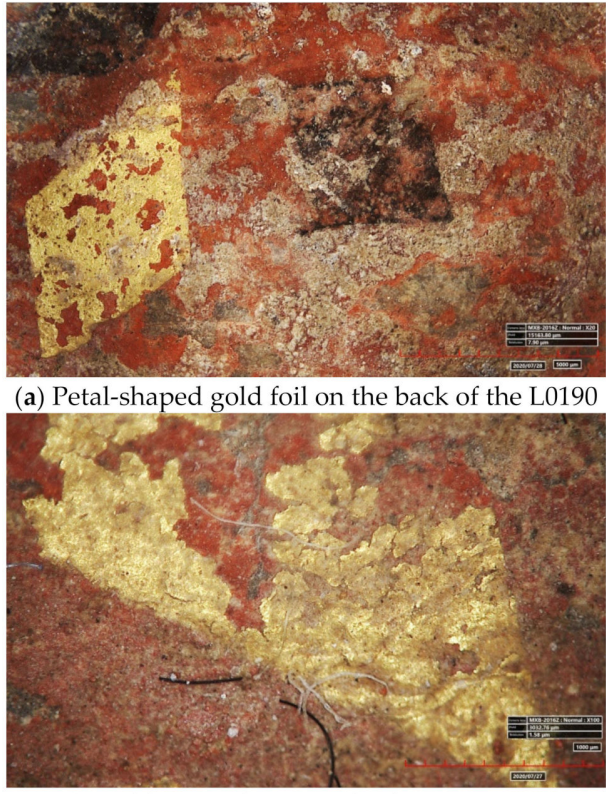

(c) Gilding on the cassock of L0203 statue

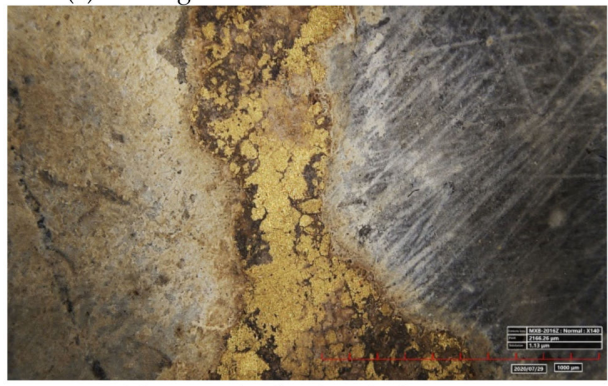

(e) Gilding on the forehead of L0144 statue

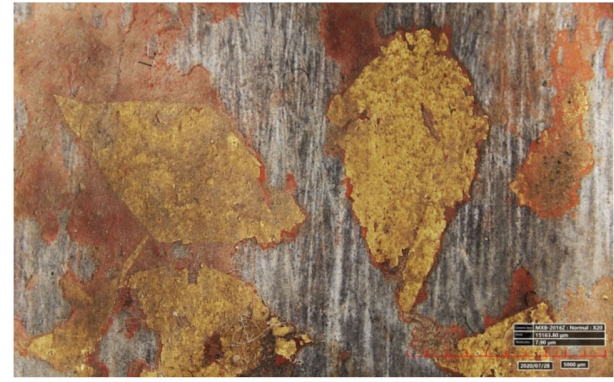

(b) Petal-shaped gold foil on the front of the L0190

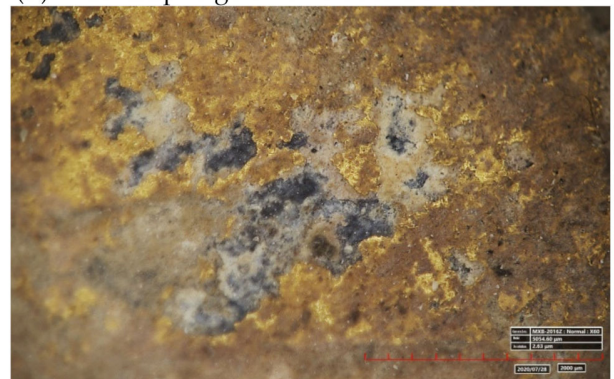

(d) Gilding under the neck of L0212 statue

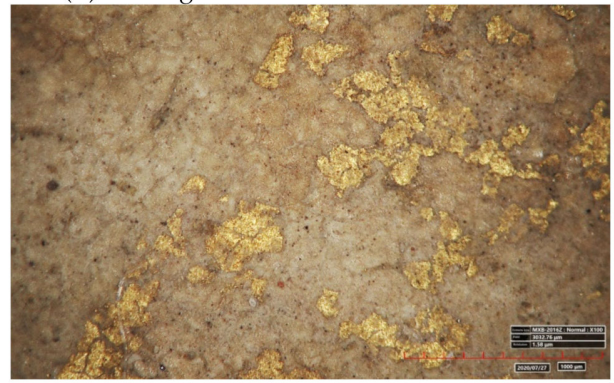

(f) Gilding on the ankle of L0196 statue

Figure 20. Gilding decoration on different statues.

After carving, most statues unearthed from the Longxing Temple site were carefully painted.

Red is the main color of most statues and used widely. It is mainly used for the cassock, halo (a circular halo drawn around the head of Buddha and Bodhisattva) and ornaments of Buddha and Bodhisattva statues, even the background color of clothes on many statues. Some statues did not seem to be painted but red pigment residue was found under the microscope, indicating that they were originally painted (Figure 15a). It is noteworthy that no ochre pigments were identified-the only red used in the works studied was cinnabar.

The application of green pigment was second only to red pigment, which can be seen with the naked eye or with the help of the microscope (Figure 15b). From the residual position of green pigment, it can be inferred that green pigment was mainly used for Seng-qi-zhi (a kind of monk's gown, draped slantingly over the left shoulder), “田 " shaped cassock and lower edge of the middle layer clothes.

Blue pigments are seldom used in large quantities on statues, probably because natural lapis lazuli is rare and valuable. The only exception is L0617, which has relatively large areas painted with blue pigment on the cassock edge. It is more difficult to find the blue pigments on other statues. With the help of the portable microscope, a small amount of residual blue pigment was found in the hair bun and coat edge of statues L0005 and L0144, respectively (Figure 15c,d). Therefore, it is speculated that the original color of the buns could have been blue. However, slightly different from L0144, the blue was significantly darker in the L005 statue. When examined under the microscope, a layer of black under the blue was found, which indicates that ancient craftsmen created a darker blue hue by layering blue over black. Except for the bun, blue pigments were also found at the edge of the outer garment and halo of the statue L0005 (Figure 15e,f). 
Lead white is generally used to make white foundation layers. The surface morphology of the selected 13 statues made of limestone was observed under portable microscope, respectively. The result shows a white foundation layer (identified with XRD as cerussite) to be on the surface of every stone body, with the color layer applied over the foundation (Figure 16). It can be inferred that when decorating the statues with paint, the craftsmen firstly made a foundation layer with lead white, and then painted on the base layer. Among the 14 statues in this study, the only one with no base layer was L0233, which is made of white marble. In this sculpture, pigments were applied directly on the stone body as observed under the microscope (Figure 17). The reason for this phenomenon is that the colors of the two kinds of stones are different. The color of limestone is generally dark, but white marble is white. In order to highlight the color of the painting and make it more dazzling, a base layer of lead white paint was applied on the limestone statues before painting. In addition to being used as a base layer, lead white is also used to paint facial features. For example, the faces of two young monks drown on the side of L0005 are also painted with lead white.

Carbon black (Chinese ink) is mainly used for drafting, sketching dress lines and decorative patterns. On both sides of the L0005 statue, there are two portraits of young monks, whose eyebrows, eyes, nose and dress lines are outlined with Chinese ink (Figure 18). In addition, black paint or ink was used to draw the cassock of Buddha, such as statue L0144. The cassock of L0144 is black, which is rare. To find out whether black is its original color or discoloration of other pigments, portable XRF was utilized to detect the elemental composition of the black cassock. The main element was lead, which should come from the base layer. Elements of some common mineral pigments, such as $\mathrm{Hg}, \mathrm{Cu}, \mathrm{As}, \mathrm{Fe}$, were not detected. The micro morphology (Figure 19) showed that the black surface was evenly distributed, and there were no particles observable under the microscope and no other color was found. Therefore, it is speculated that the black cassock is its original color, and the pigment used may be carbon black or Chinese ink. According to some ancient Chinese documents, during the Northern and Southern Dynasties (the 6th century C.E.), monks did have the habit of wearing black cassocks, such as the eminent monks Huilin, Senghui and Xuanchang.

The statues unearthed from Longxing Temple site have been buried underground for nearly a thousand years, and most of them have been damaged to some extent before being buried, although the reason for the damage and burial is unclear and may relate to a catastrophic event or to persecutions of Buddhists during the Northern Zhou period [24]. The gold layer on the surface is also damaged to varying extent. The results of potable XRF analysis suggest that the gilding materials are made of high purity gold leaf, but further invasive analysis would be required using SEM-EDX to assess the presence of other metals in the gold. In order to understand the stratigraphy and identify the gilding techniques, the gilded surfaces of 14 statues were observed under magnification. In some areas, gold foil is glued on the painted layer (Figure 20a-c), most of which are decorative patterns. After the painting is completed, the gold foil is cut in advance (for example, the diamonds in Figure 20a-c, which form a Petal pattern) and pasted as decoration. Some gold is directly applied to the white foundation layer, which occurs mostly in the face, neck, bare chest, hands and feet (Figure 20d,e). In the area of gold foil falling off, some black marks are left on the surface of the gilding area (Figure 20a). It is speculated that a kind of gold gluing oil, which is a traditional Chinese binding material usually used for gilding [25,26], may have been used in the gilding process. Pyrolysis-gas chromatography/mass spectrum (Py-GC/MS) analysis of gilding would potentially aid in the identification of original organic media [27-29] but is limited by sample requirements. 


\section{Conclusions}

Most statues unearthed from the Longxing Temple site in Qingzhou date from the Northern Wei Dynasty to Northern Qi Dynasty. The majority of the works selected in this study date from the Northern Qi Dynasty (two in Eastern Wei Dynasty, one in Eastern Wei-North Qi Dynasty and eleven in the Northern Qi Dynasty). Similar painting materials are found on all the statues, which suggested remarkable consistency in the use of pigments, even if the reason for this strong similarity is not clear but may be related to local production: Cinnabar (red), malachite (green), lapis lazuli (blue), lead white (white), carbon black (Chinese ink) and gold foil (gilded areas) were identified.

After the sculptures were finished, most of the surfaces were generally polished. Then, a foundation layer of lead white was applied on the stone body (except L0233, the only work studied made of white marble). Finally, painting and gilding were applied over the foundation layer. Red pigment was employed for the cassock, halo and ornaments of Buddha and Bodhisattva statues. Green pigment was chosen for Seng-qi-zhi (a kind of monk's gown, draped slantingly over the left shoulder), “田" shaped cassock and lower edge of middle layer clothes. Chinese ink was used for drafting, sketching dress lines and decorative patterns.

At present, the majority of statues unearthed from the Longxing Temple site cannot be sampled, thus in situ nondestructive analysis has become a priority. In the paper, portable $\mathrm{XRF}$, a Raman spectrometer and a 3D video microscope were used to study the statues on site, but Raman analysis was compromised by fluorescence ascribed to conservation materials. Laboratory analysis using confocal Raman spectroscopy was used to identify ultramarine. In our work, microscopic examination has been particularly important to understand the condition of the paint, the stratigraphy of paint and the gilding technology. Based on the significant number of works studied, these results reflect the materials and techniques of the statues made from the Eastern Wei to Bei Qi period in Qingzhou, China. Future research should determine the binding media employed both for paint and gilding, and could build on our knowledge of the trade and production of pigments.

Author Contributions: Conceptualization, Y.S.; methodology, Y.W.; software, F.L.; validation, Y.W., F.L. and Y.S.; formal analysis, Y.S.; investigation, Y.S., J.G., L.Z. and R.W.; resources, L.Z. and R.W.; data curation, F.L.; writing —original draft preparation, Y.S.; writing—review and editing, Y.S. and A.N.; visualization, J.G.; supervision, Y.S.; project administration, Y.S.; funding acquisition, Y.S. All authors have read and agreed to the published version of the manuscript.

Funding: This research was funded by Basic Research Project Fund of Chinese Academy of Cultural Heritage, 2019JBKY08.

Institutional Review Board Statement: Not applicable.

Informed Consent Statement: Informed consent was obtained from all subjects involved in the study.

Conflicts of Interest: The authors declare no conflict of interest. 
Appendix A. High-Definition Images of 8 Statues

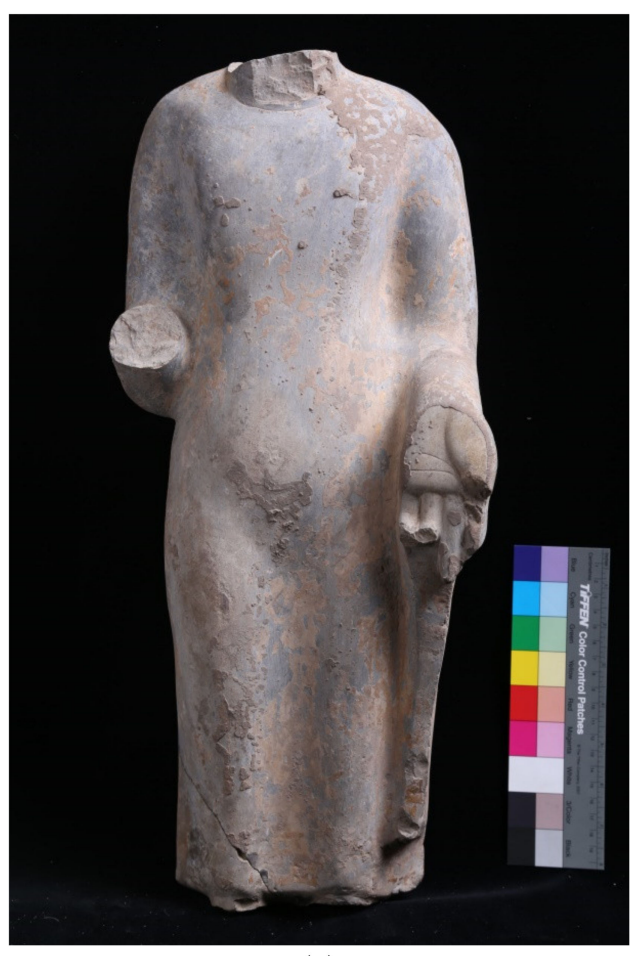

(a)

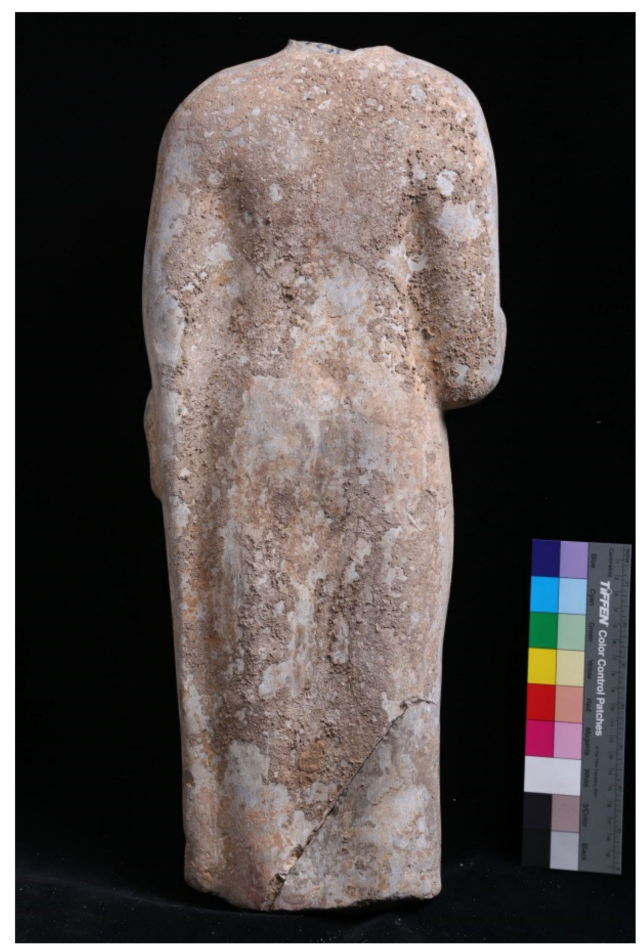

(b)

Figure A1. Front (a) and back (b) of L0196.

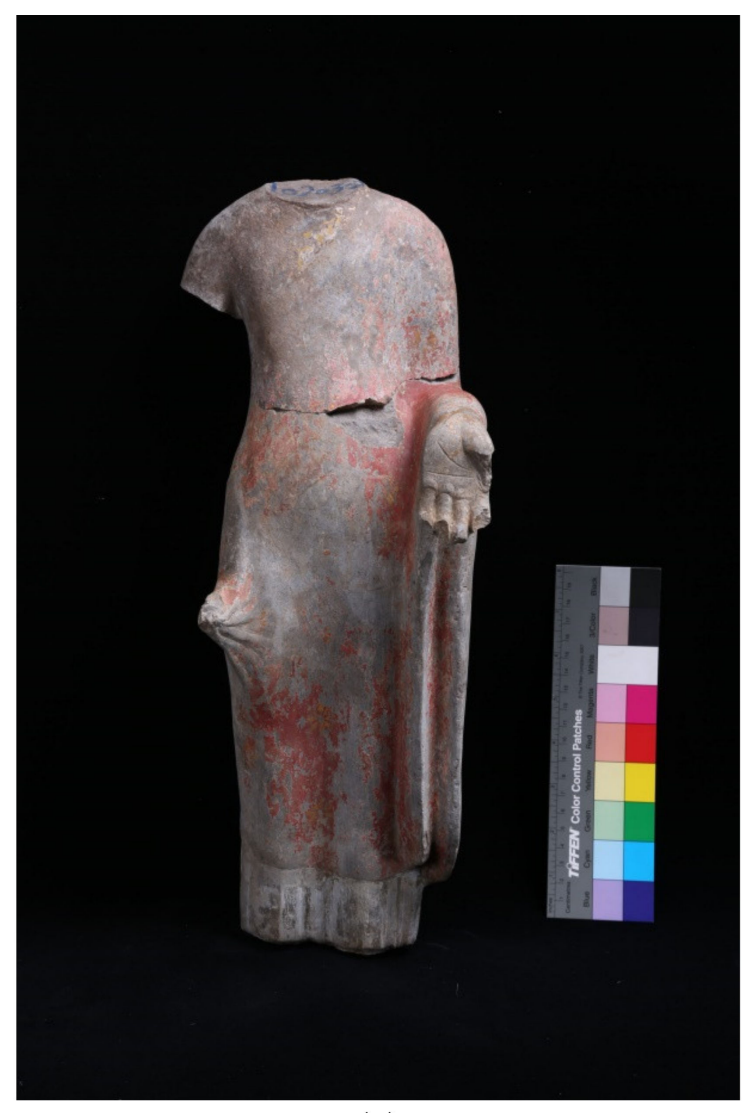

(a)

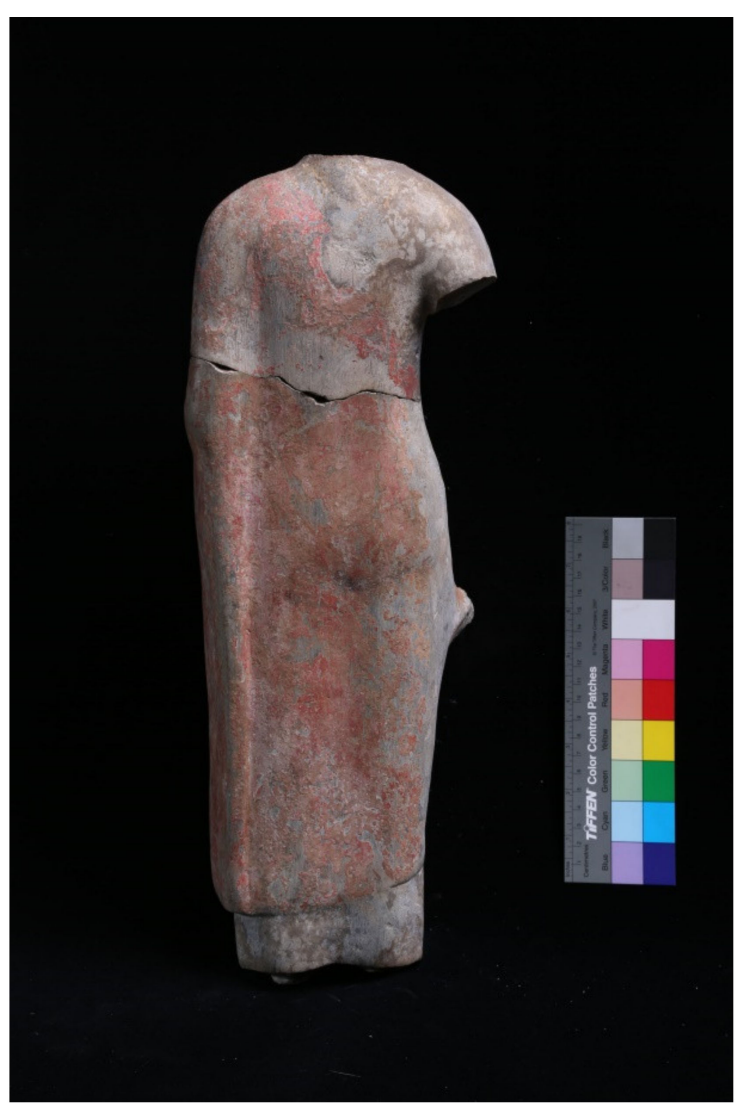

(b)

Figure A2. Front (a) and back (b) of L0203. 


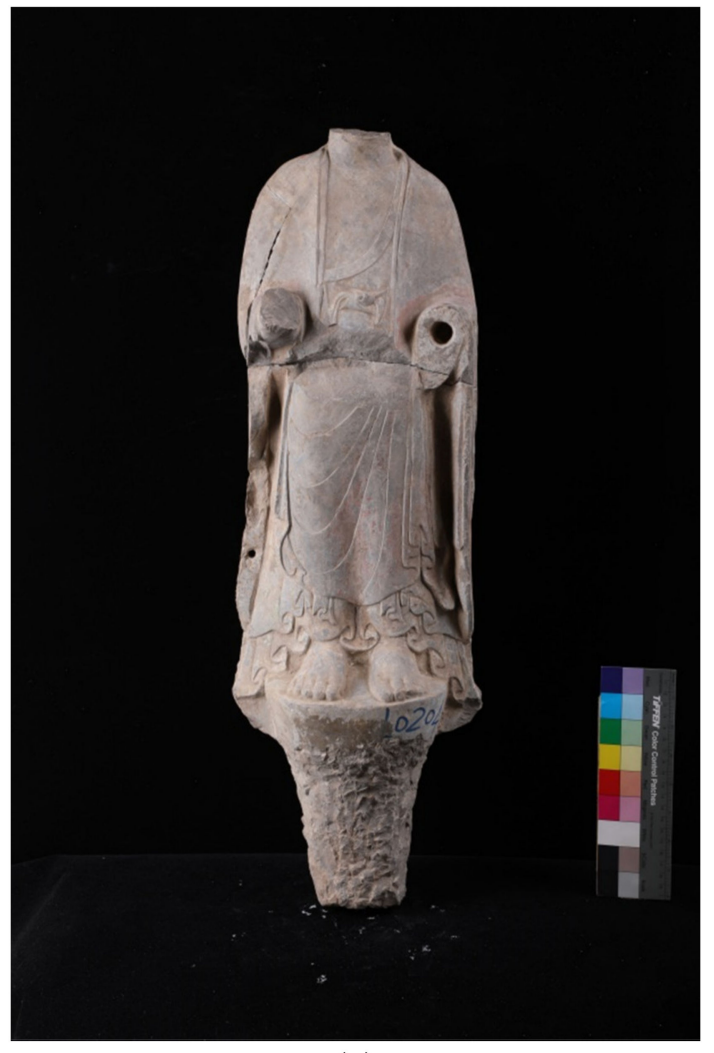

(a)

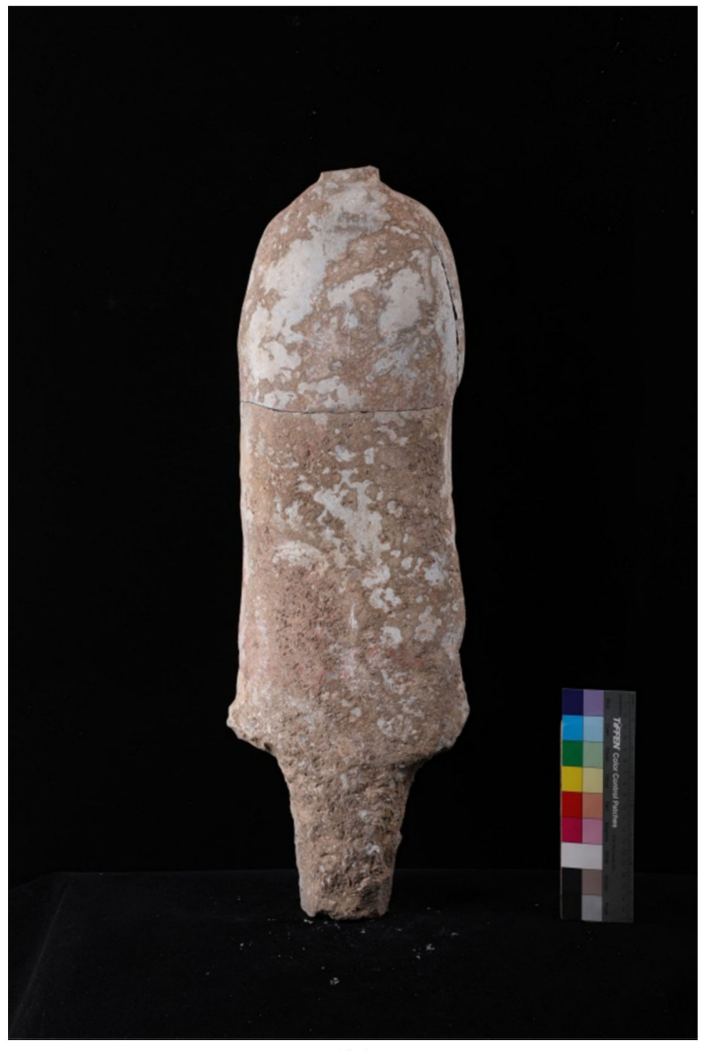

(b)

Figure A3. Front (a) and back (b) of L0204.

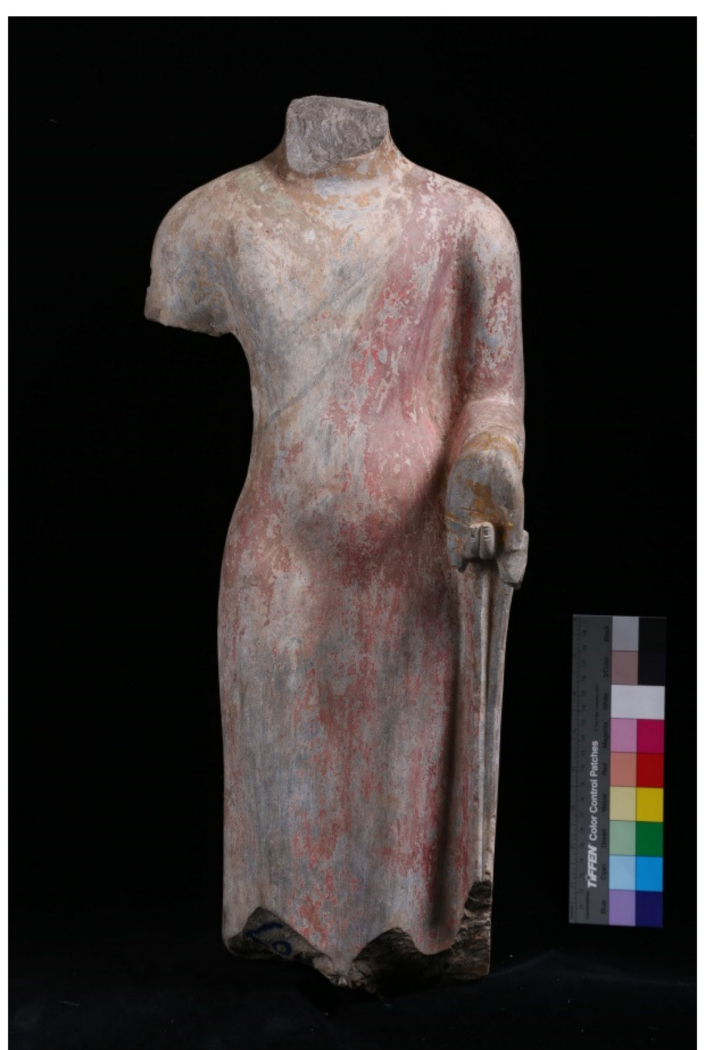

(a)

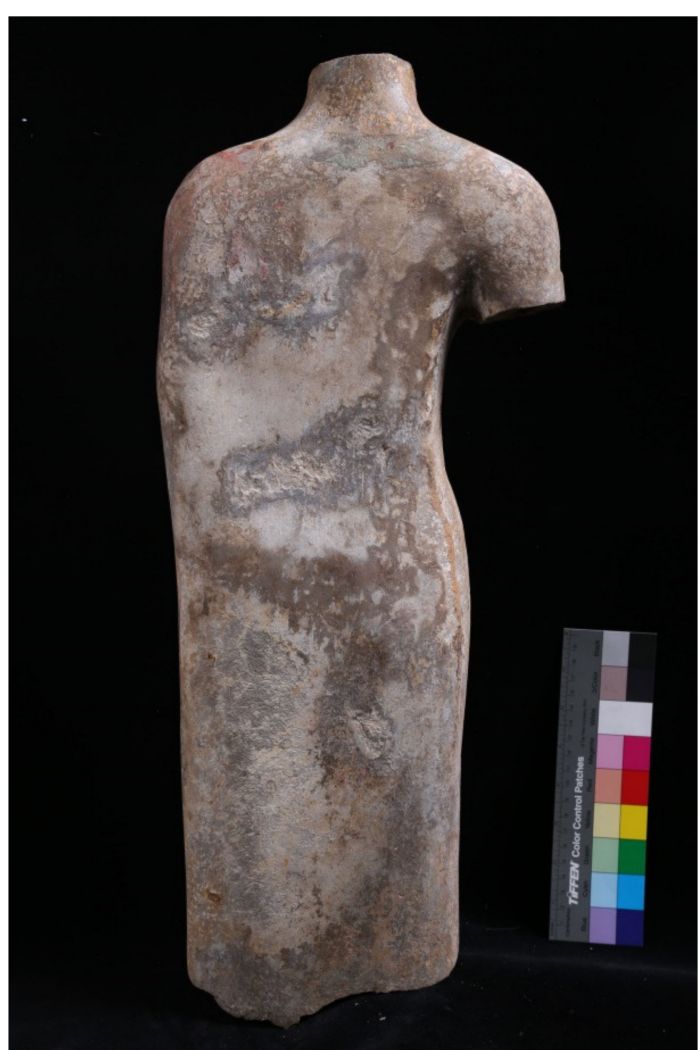

(b)

Figure A4. Front (a) and back (b) of L0212. 


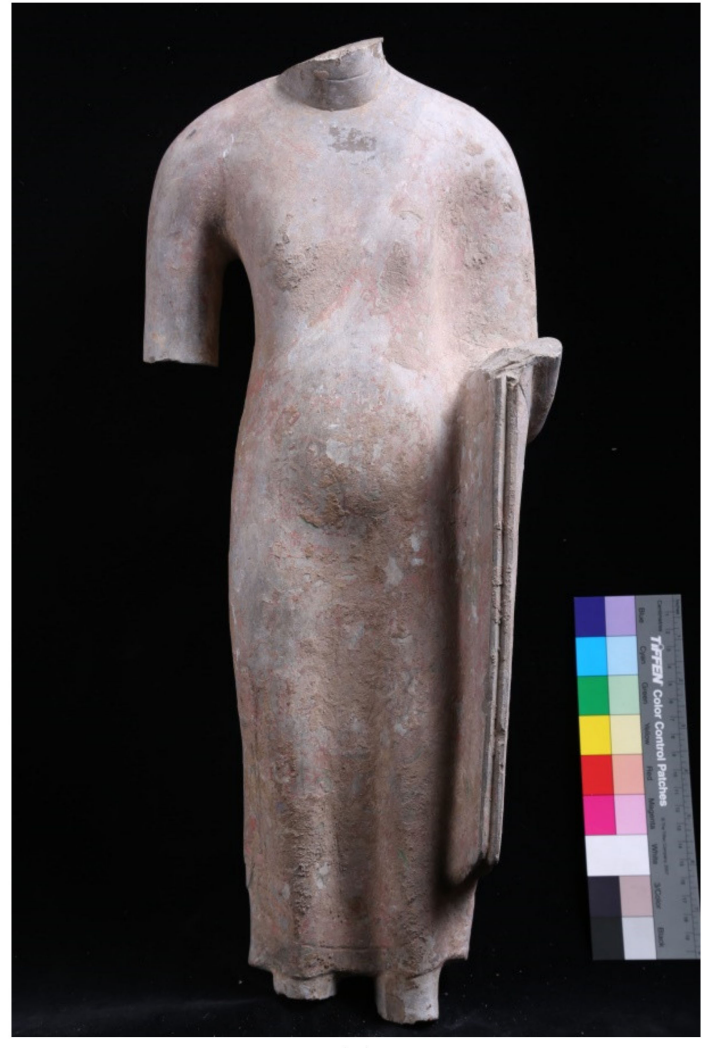

(a)

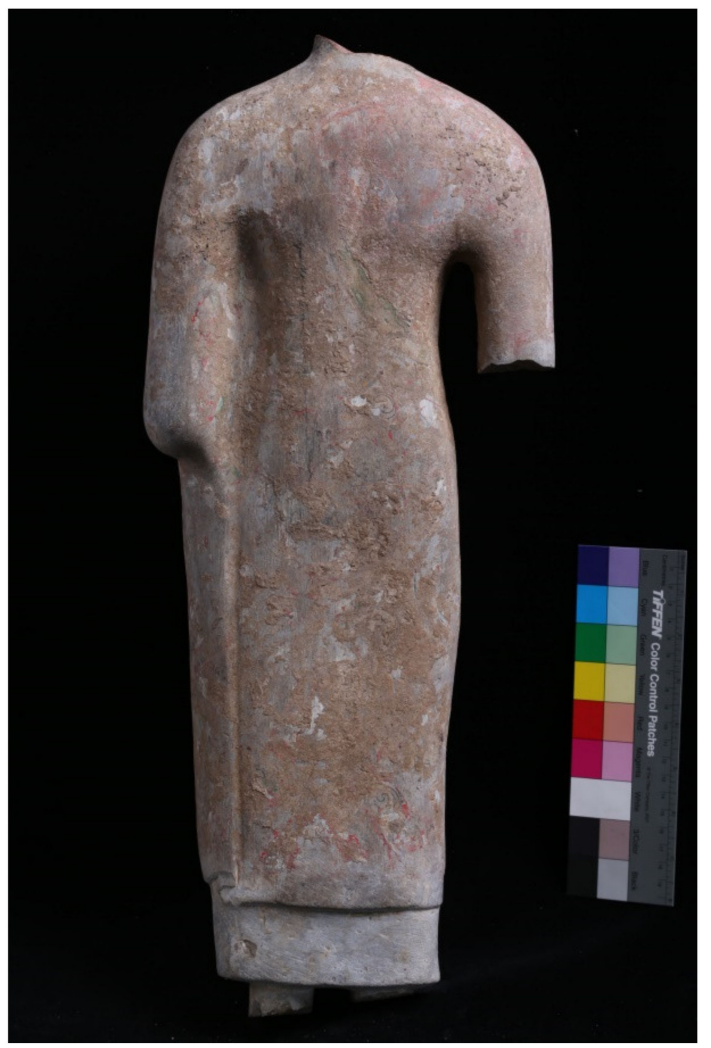

(b)

Figure A5. Front (a) and back (b) of L0219.

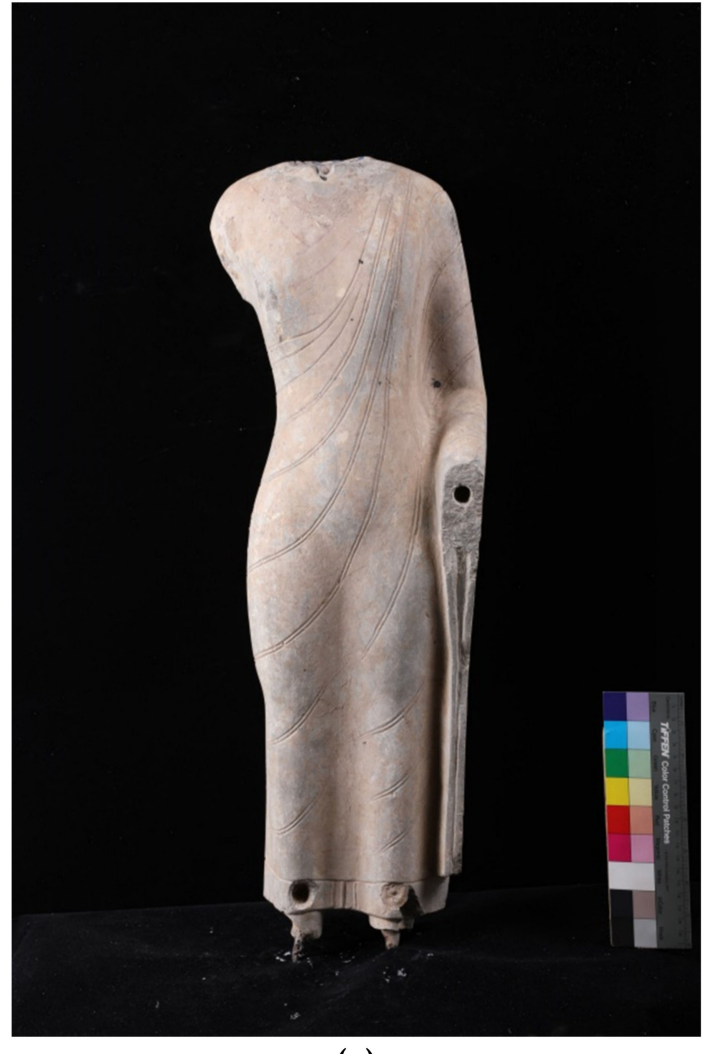

(a)

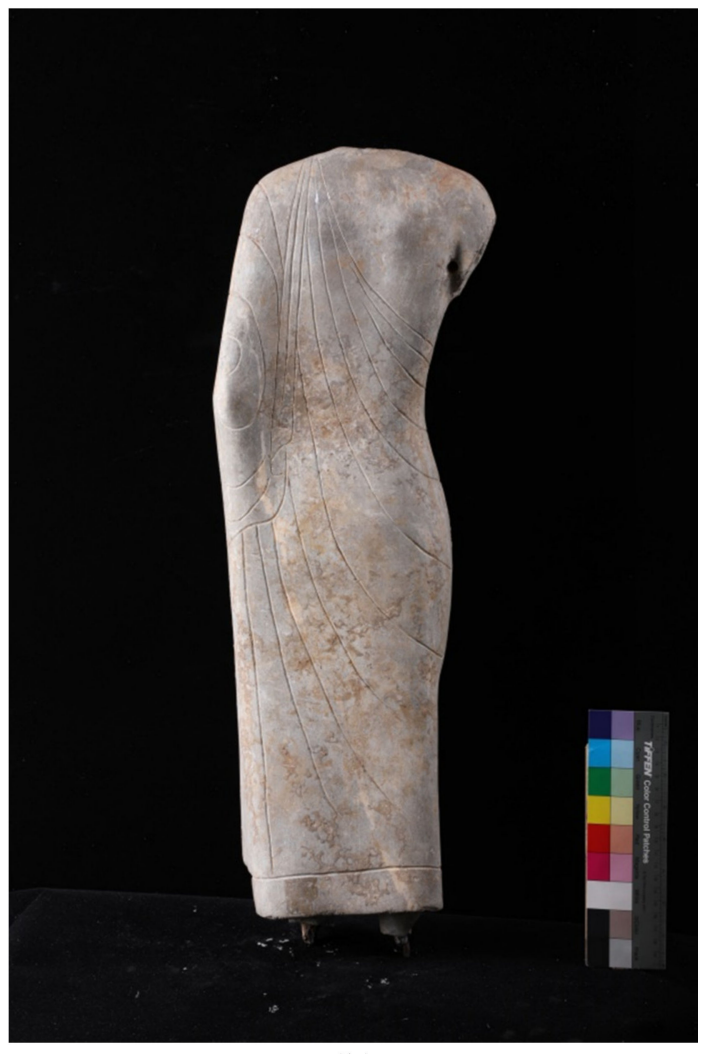

(b)

Figure A6. Front (a) and back (b) of L0229. 


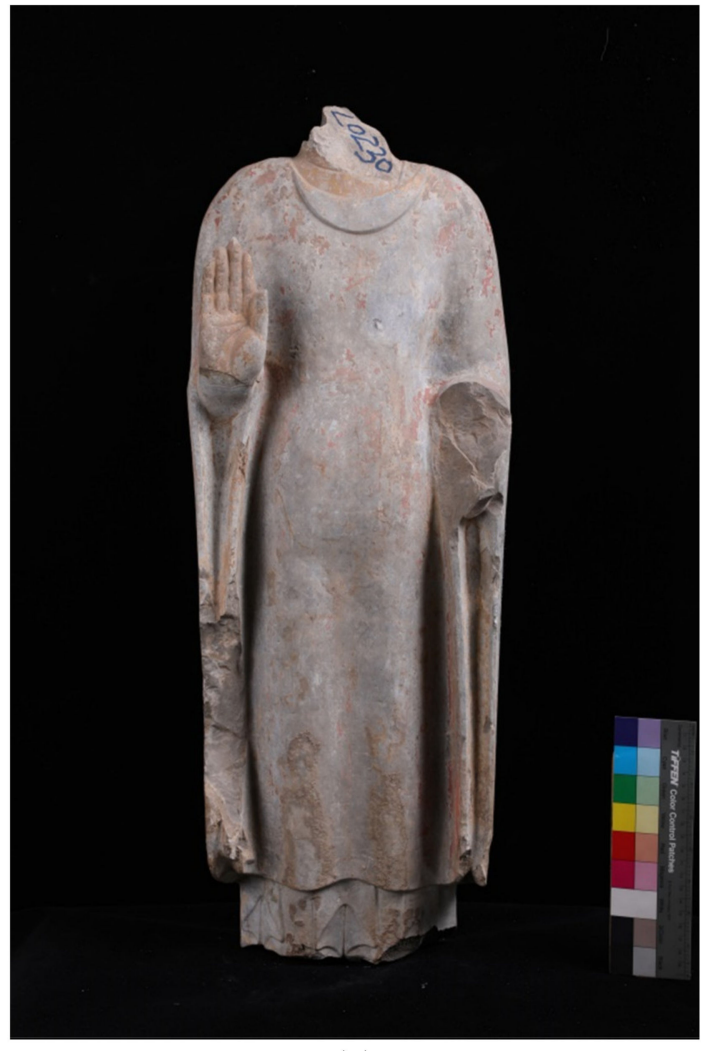

(a)

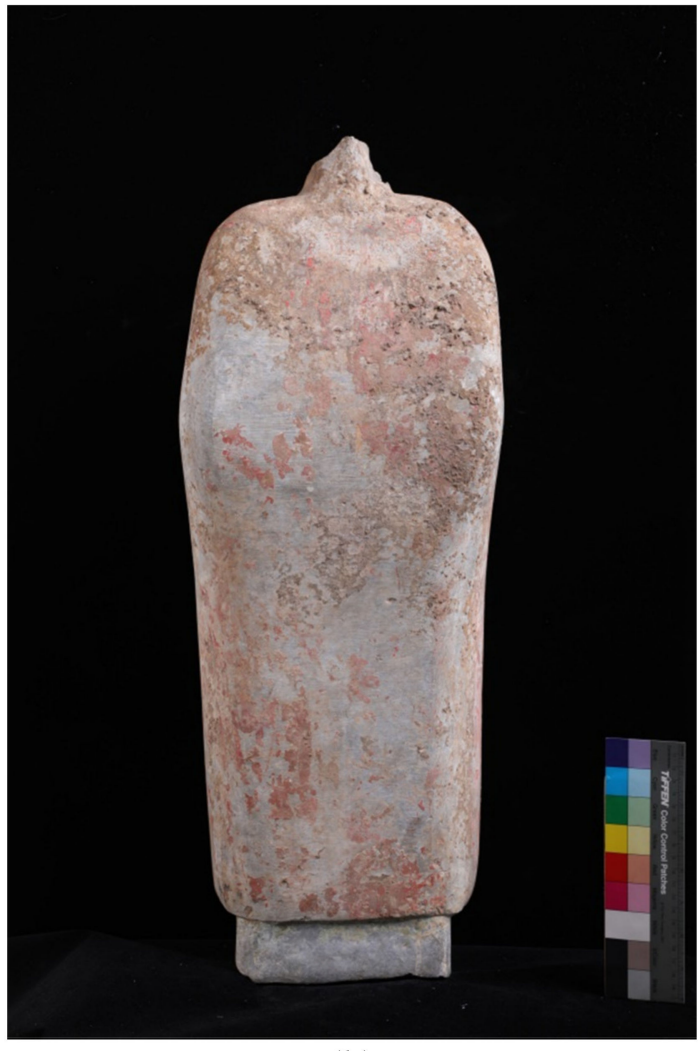

(b)

Figure A7. Front (a) and back (b) of L0230.

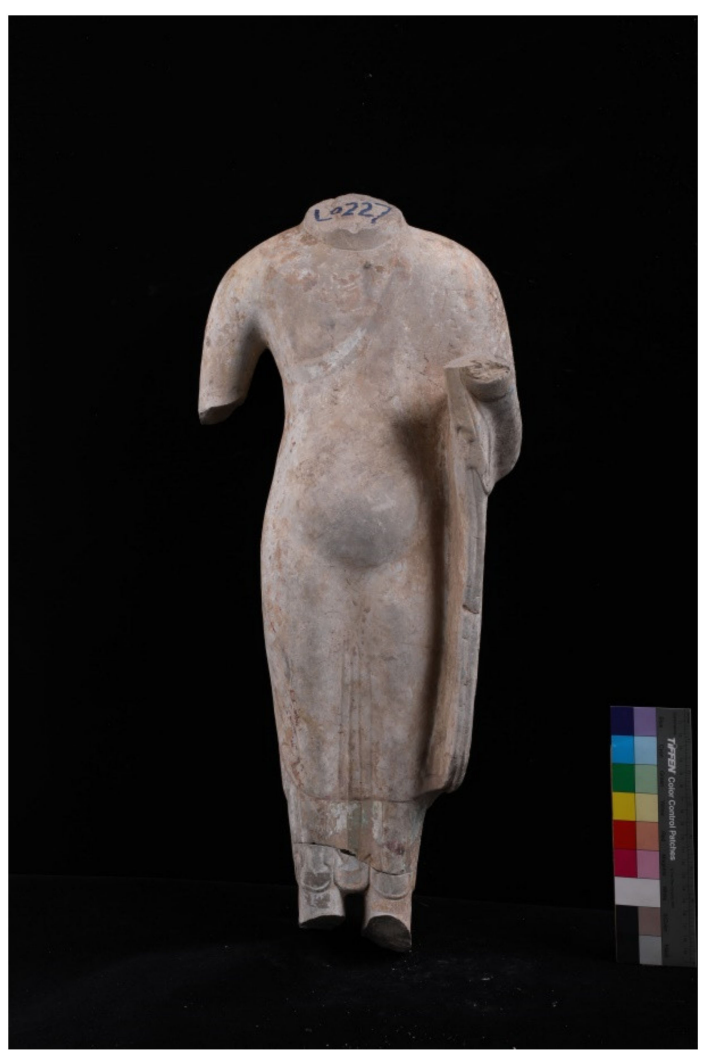

(a)

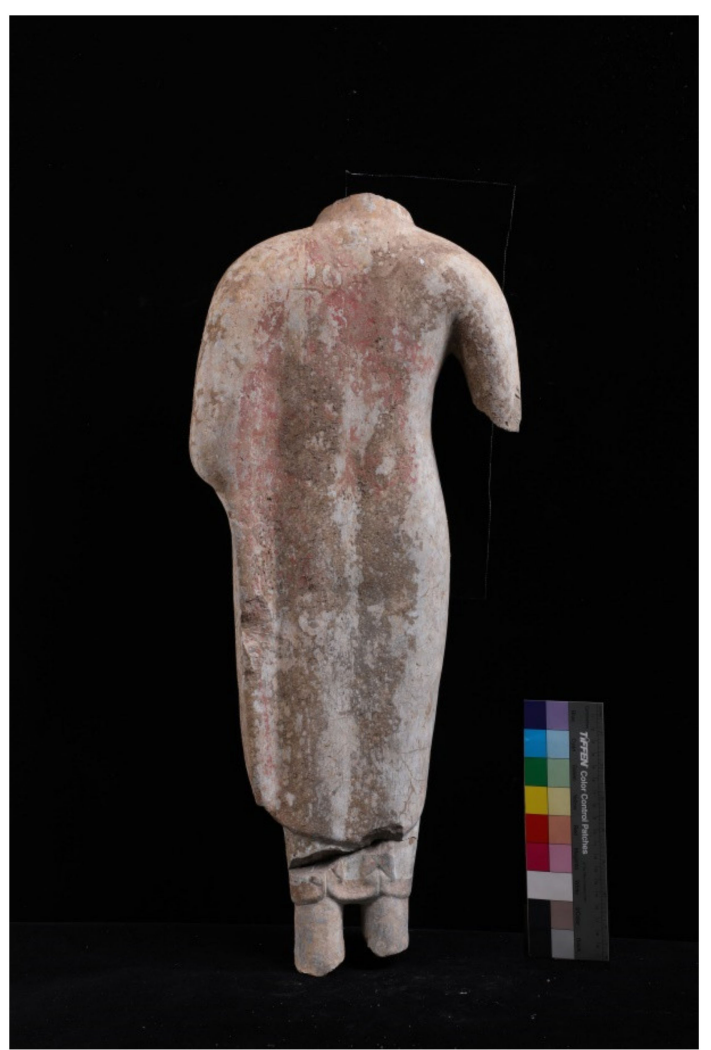

(b)

Figure A8. Front (a) and back (b) of L0227. 


\section{Appendix B}

Table A1. Results of the In-Situ XRF Analysis Carried on the 13 Buddhist Statues Investigated in this Study.

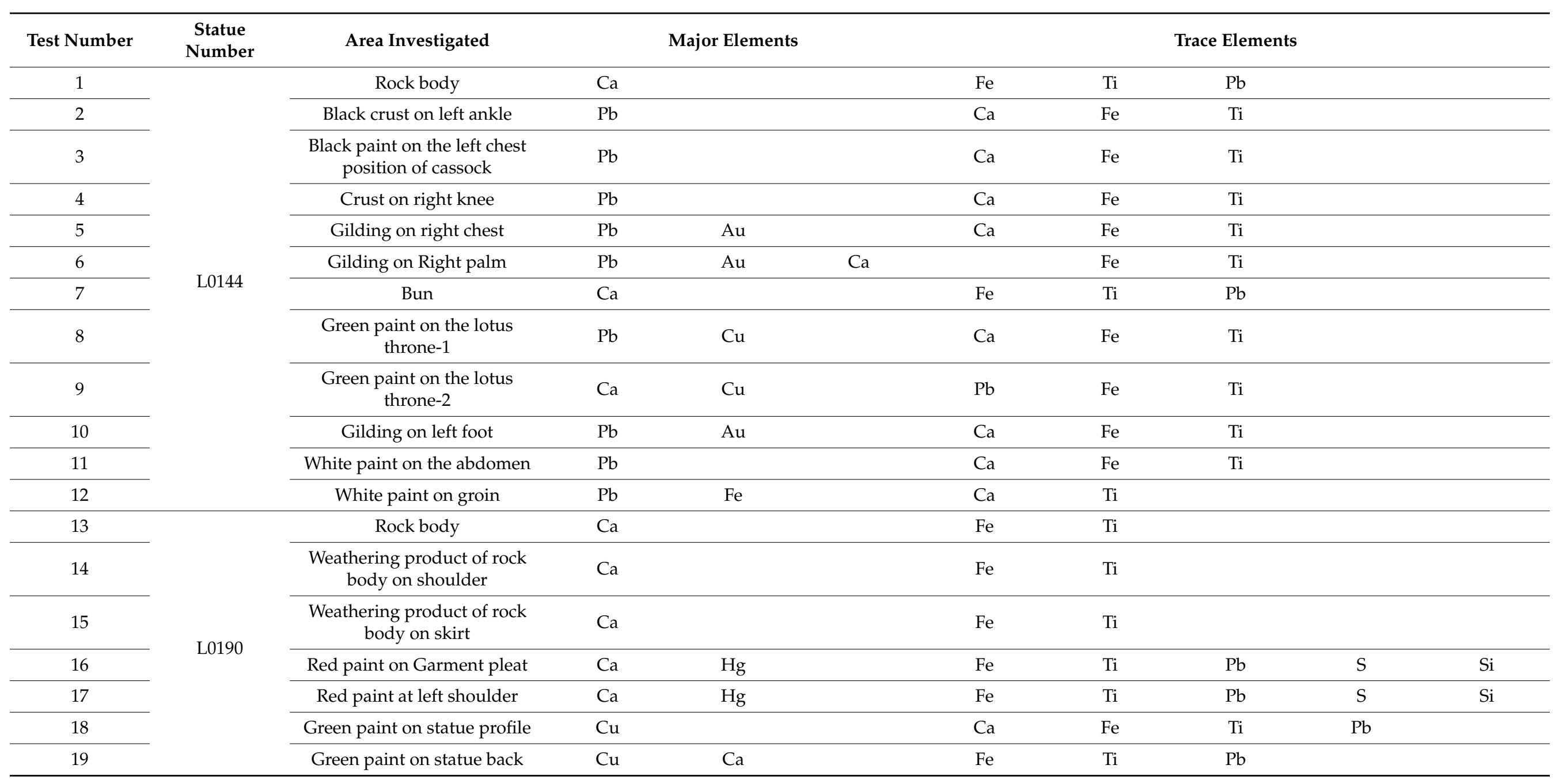


Table A1. Cont.

\begin{tabular}{|c|c|c|c|c|c|c|c|c|c|c|}
\hline \multirow{2}{*}{$\begin{array}{c}\text { Test Number } \\
20\end{array}$} & \multirow[t]{2}{*}{$\begin{array}{c}\text { Statue } \\
\text { Number }\end{array}$} & \multirow{2}{*}{$\begin{array}{c}\text { Area Investigated } \\
\text { Petal pattern gold-1 }\end{array}$} & \multicolumn{3}{|c|}{ Major Elements } & \multicolumn{5}{|c|}{ Trace Elements } \\
\hline & & & $\mathrm{Ca}$ & $\mathrm{Hg}$ & & $\mathrm{Fe}$ & $\mathrm{Ti}$ & $\mathrm{Pb}$ & & \\
\hline 21 & & Petal pattern gold-2 & $\mathrm{Ca}$ & $\mathrm{Hg}$ & & $\mathrm{Fe}$ & $\mathrm{Ti}$ & $\mathrm{Pb}$ & $\mathrm{S}$ & $\mathrm{Si}$ \\
\hline 22 & & Blue paint on the ankle & $\mathrm{Ca}$ & & & $\mathrm{Fe}$ & $\mathrm{Ti}$ & & & \\
\hline 23 & & $\begin{array}{l}\text { Blue paint on the hem of } \\
\text { sleeves }\end{array}$ & $\mathrm{Ca}$ & & & $\mathrm{Fe}$ & $\mathrm{Ti}$ & & & \\
\hline 25 & & Black matter on the abdomen & $\mathrm{Ca}$ & & & $\mathrm{Fe}$ & $\mathrm{Ti}$ & & & \\
\hline 26 & & Gold on the chest of Buddha & $\mathrm{Pb}$ & $\mathrm{Au}$ & & $\mathrm{Ca}$ & $\mathrm{Fe}$ & $\mathrm{Ti}$ & & \\
\hline 27 & & $\begin{array}{l}\text { Green paint on the belly of } \\
\text { Buddha }\end{array}$ & $\mathrm{Cu}$ & $\mathrm{Ca}$ & & $\mathrm{Fe}$ & $\mathrm{Ti}$ & $\mathrm{Pb}$ & & \\
\hline 28 & \multirow{5}{*}{ L0196 } & Rock body & $\mathrm{Ca}$ & & & $\mathrm{Fe}$ & $\mathrm{Ti}$ & & & \\
\hline 29 & & Red paint on the ankle & $\mathrm{Pb}$ & $\mathrm{S}$ & $\mathrm{Ca}$ & $\mathrm{Fe}$ & $\mathrm{Ti}$ & $\mathrm{Au}$ & $\mathrm{S}$ & $\mathrm{Si}$ \\
\hline 30 & & Gold at cuff & $\mathrm{Au}$ & $\mathrm{Pb}$ & $\mathrm{Ca}$ & $\mathrm{Fe}$ & $\mathrm{Ti}$ & $\mathrm{S}$ & $\mathrm{Si}$ & \\
\hline 31 & & $\begin{array}{l}\text { White paint on the left upper } \\
\text { arm }\end{array}$ & $\mathrm{Pb}$ & $\mathrm{Ca}$ & & $\mathrm{Fe}$ & $\mathrm{Ti}$ & $\mathrm{S}$ & $\mathrm{Si}$ & \\
\hline 32 & & $\begin{array}{l}\text { White paint on the palm of } \\
\text { Buddha }\end{array}$ & $\mathrm{Ca}$ & & & $\mathrm{Fe}$ & $\mathrm{Ti}$ & $S$ & & \\
\hline 33 & \multirow{4}{*}{ L0203 } & Rock body & $\mathrm{Ca}$ & & & $\mathrm{Fe}$ & $\mathrm{Ti}$ & $S$ & & \\
\hline 34 & & $\begin{array}{l}\text { Red paint on the calf of } \\
\text { Buddha }\end{array}$ & $\mathrm{Ca}$ & $\mathrm{Hg}$ & $\mathrm{Pb}$ & $\mathrm{Fe}$ & $\mathrm{Ti}$ & $\mathrm{S}$ & & \\
\hline 35 & & $\begin{array}{c}\text { Gold on the right leg of } \\
\text { Buddha }\end{array}$ & $\mathrm{Ca}$ & $\mathrm{Au}$ & & $\mathrm{Fe}$ & $\mathrm{Ti}$ & $\mathrm{S}$ & & \\
\hline 36 & & Gold at neckline & $\mathrm{Ca}$ & $\mathrm{Pb}$ & & $\mathrm{Au}$ & $\mathrm{Fe}$ & $\mathrm{Ti}$ & & \\
\hline 37 & \multirow{2}{*}{ L0204 } & Rock body & $\mathrm{Ca}$ & & & $\mathrm{Fe}$ & $\mathrm{Ti}$ & & & \\
\hline 38 & & Red paint on the leg & $\mathrm{Ca}$ & $\mathrm{Hg}$ & $\mathrm{Pb}$ & $\mathrm{Fe}$ & $\mathrm{Ti}$ & $S$ & $\mathrm{Si}$ & \\
\hline
\end{tabular}


Table A1. Cont.

\begin{tabular}{|c|c|c|c|c|c|c|c|c|c|c|}
\hline \multirow{2}{*}{$\begin{array}{c}\text { Test Number } \\
39 \\
\end{array}$} & \multirow[t]{2}{*}{$\begin{array}{c}\text { Statue } \\
\text { Number }\end{array}$} & \multirow{2}{*}{$\begin{array}{c}\text { Area Investigated } \\
\text { Rock body }\end{array}$} & \multicolumn{3}{|c|}{ Major Elements } & \multicolumn{5}{|c|}{ Trace Elements } \\
\hline & & & $\mathrm{Ca}$ & $\mathrm{Pb}$ & & $\mathrm{Fe}$ & $\mathrm{Ti}$ & & & \\
\hline 40 & \multirow{3}{*}{ L0212 } & Red paint on the abdomen & $\mathrm{Ca}$ & $\mathrm{Hg}$ & $\mathrm{Pb}$ & $\mathrm{Fe}$ & $\mathrm{Ti}$ & $\mathrm{S}$ & $\mathrm{Si}$ & \\
\hline 41 & & Black stripe & $\mathrm{Ca}$ & & & $\mathrm{Fe}$ & $\mathrm{Ti}$ & $\mathrm{Cu}$ & $\mathrm{Pb}$ & \\
\hline 42 & & Gold on the palm & $\mathrm{Ca}$ & & & $\mathrm{Fe}$ & $\mathrm{Ti}$ & $\mathrm{Au}$ & $\mathrm{Pb}$ & \\
\hline 43 & \multirow{6}{*}{ L0219 } & Rock body & $\mathrm{Ca}$ & & & $\mathrm{Fe}$ & $\mathrm{Ti}$ & $\mathrm{S}$ & & \\
\hline 45 & & Red paint on the thigh & $\mathrm{Fe}$ & $\mathrm{Ca}$ & & $\mathrm{Ti}$ & $\mathrm{Hg}$ & $\mathrm{S}$ & & \\
\hline 46 & & Green paint at the lower leg & $\mathrm{Ca}$ & $\mathrm{Fe}$ & $\mathrm{Cu}$ & $\mathrm{Ti}$ & S & $\mathrm{Pb}$ & & \\
\hline 47 & & Green paint on the sleeves & $\mathrm{Ca}$ & $\mathrm{Fe}$ & $\mathrm{Cu}$ & $\mathrm{Ti}$ & $S$ & $\mathrm{~Pb}$ & & \\
\hline 48 & & Green paint on the abdomen & $\mathrm{Ca}$ & $\mathrm{Fe}$ & $\mathrm{Cu}$ & $\mathrm{Ti}$ & $S$ & $\mathrm{~Pb}$ & $\mathrm{~K}$ & \\
\hline 49 & & Red paint on the abdomen & $\mathrm{Ca}$ & $\mathrm{Fe}$ & & $\mathrm{Ti}$ & $\mathrm{Hg}$ & $\mathrm{Pb}$ & $\mathrm{S}$ & $\mathrm{Si}$ \\
\hline 50 & \multirow{3}{*}{ L0227 } & Rock body & $\mathrm{Ca}$ & & & $\mathrm{Fe}$ & $\mathrm{Ti}$ & & & \\
\hline 52 & & Black matter on the abdomen & $\mathrm{Ca}$ & & & $\mathrm{Fe}$ & $\mathrm{Ti}$ & & & \\
\hline 53 & & Red paint on the right knee & $\mathrm{Ca}$ & & & $\mathrm{Fe}$ & $\mathrm{Ti}$ & $\mathrm{Hg}$ & $\mathrm{Pb}$ & $\mathrm{S}$ \\
\hline 54 & \multirow{3}{*}{ L0229 } & Rock body & $\mathrm{Ca}$ & & & $\mathrm{Fe}$ & $\mathrm{Ti}$ & $S$ & & \\
\hline 55 & & Red paint on the right foot & $\mathrm{Ca}$ & $\mathrm{Pb}$ & & $\mathrm{Fe}$ & $\mathrm{Ti}$ & $S$ & & \\
\hline 56 & & Red paint on the Neckline & $\mathrm{Ca}$ & $\mathrm{Pb}$ & & $\mathrm{Fe}$ & $\mathrm{Ti}$ & $S$ & & \\
\hline 57 & \multirow{2}{*}{ L0230 } & Rock body & $\mathrm{Ca}$ & & & $\mathrm{Fe}$ & $\mathrm{Ti}$ & & & \\
\hline 58 & & Red paint on the shoulder & $\mathrm{Ca}$ & & & $\mathrm{Fe}$ & $\mathrm{Ti}$ & $\mathrm{Hg}$ & $\mathrm{Pb}$ & $S$ \\
\hline 59 & \multirow{5}{*}{ L0233 } & Black matter-1 & $\mathrm{Ca}$ & & & $\mathrm{Fe}$ & $\mathrm{Ti}$ & $\mathrm{Pb}$ & $\mathrm{S}$ & \\
\hline 60 & & Black matter-2 & $\mathrm{Ca}$ & & & $\mathrm{Fe}$ & $\mathrm{Ti}$ & $\mathrm{Pb}$ & $\mathrm{Cu}$ & $S$ \\
\hline 61 & & Black matter-3 & $\mathrm{Ca}$ & & & $\mathrm{Fe}$ & $\mathrm{Ti}$ & $\mathrm{Pb}$ & $\mathrm{Si}$ & \\
\hline 62 & & Rock body & $\mathrm{Ca}$ & & & $\mathrm{Fe}$ & $\mathrm{Ti}$ & & & \\
\hline 63 & & Red paint on the thigh & $\mathrm{Ca}$ & $\mathrm{Hg}$ & & $\mathrm{Fe}$ & $\mathrm{Ti}$ & $\mathrm{Pb}$ & $\mathrm{S}$ & $\mathrm{Si}$ \\
\hline
\end{tabular}


Table A1. Cont.

\begin{tabular}{|c|c|c|c|c|c|c|c|c|c|c|}
\hline \multirow{2}{*}{$\begin{array}{c}\text { Test Number } \\
64 \\
\end{array}$} & \multirow[t]{2}{*}{$\begin{array}{c}\text { Statue } \\
\text { Number }\end{array}$} & Area Investigated & \multicolumn{3}{|c|}{ Major Elements } & \multicolumn{5}{|c|}{ Trace Elements } \\
\hline & & Red paint on the lower leg & $\mathrm{Ca}$ & $\mathrm{Hg}$ & & $\mathrm{Fe}$ & $\mathrm{Ti}$ & $\mathrm{Pb}$ & $\mathrm{S}$ & \\
\hline 65 & & Gold on the chest- 1 & $\mathrm{Ca}$ & $\mathrm{Cu}$ & $\mathrm{Au}$ & $\mathrm{Fe}$ & $\mathrm{Ti}$ & & & \\
\hline 66 & & Gold on the chest- 2 & $\mathrm{Ca}$ & $\mathrm{Au}$ & $\mathrm{Pb}$ & $\mathrm{Fe}$ & $\mathrm{Ti}$ & & & \\
\hline 67 & & $\begin{array}{c}\text { Circle at the bottom of the } \\
\text { skirt }\end{array}$ & $\mathrm{Ca}$ & $\mathrm{Au}$ & $\mathrm{Pb}$ & $\mathrm{Fe}$ & $\mathrm{Ti}$ & & & \\
\hline 69 & & Green paint on the crotch & $\mathrm{Ca}$ & $\mathrm{Cu}$ & & $\mathrm{Fe}$ & $\mathrm{Ti}$ & $\mathrm{Au}$ & $\mathrm{Pb}$ & K \\
\hline 70 & \multirow{7}{*}{ L0617 } & Rock body & $\mathrm{Ca}$ & & & $\mathrm{Fe}$ & $\mathrm{Ti}$ & & & \\
\hline 71 & & Red paint on the back & $\mathrm{Pb}$ & $\mathrm{Hg}$ & & $\mathrm{Ca}$ & $\mathrm{Ti}$ & $\mathrm{Fe}$ & $\mathrm{S}$ & $\mathrm{Si}$ \\
\hline 72 & & Green paint on the back & $\mathrm{Ca}$ & $\mathrm{Cu}$ & & $\mathrm{Fe}$ & $\mathrm{Ti}$ & $\mathrm{Pb}$ & & \\
\hline 73 & & Black paint on the side & $\mathrm{Ca}$ & & & $\mathrm{Fe}$ & $\mathrm{Ti}$ & $\mathrm{Cu}$ & & \\
\hline 74 & & Blue paint on the side & $\mathrm{Ca}$ & $\mathrm{Cu}$ & & $\mathrm{Fe}$ & $\mathrm{Ti}$ & $\mathrm{Si}$ & & \\
\hline 76 & & Gold on the front & $\mathrm{Ca}$ & $\mathrm{Au}$ & $\mathrm{Hg}$ & $\mathrm{Fe}$ & $\mathrm{Ti}$ & $\mathrm{Cu}$ & $\mathrm{S}$ & $\mathrm{Si}$ \\
\hline 77 & & $\begin{array}{c}\text { White dot above the black } \\
\text { matter }\end{array}$ & $\mathrm{Ca}$ & $\mathrm{Cu}$ & $\mathrm{Pb}$ & $\mathrm{Fe}$ & $\mathrm{Ti}$ & $\mathrm{Si}$ & & \\
\hline 78 & \multirow{5}{*}{ L0005 } & Red mark on the left side & $\mathrm{Ca}$ & & & $\mathrm{Fe}$ & $\mathrm{Ti}$ & $\mathrm{Pb}$ & & \\
\hline 79 & & $\begin{array}{l}\text { Red paint on the ribbon of } \\
\text { left Buddha }\end{array}$ & $\mathrm{Ca}$ & $\mathrm{Hg}$ & $\mathrm{Pb}$ & $\mathrm{Fe}$ & $\mathrm{Ti}$ & $\mathrm{S}$ & & \\
\hline 80 & & $\begin{array}{l}\text { Red paint on the skirt of left } \\
\text { Buddha }\end{array}$ & $\mathrm{Ca}$ & $\mathrm{Hg}$ & $\mathrm{Pb}$ & $\mathrm{Fe}$ & $\mathrm{Ti}$ & $\mathrm{S}$ & & \\
\hline 81 & & $\begin{array}{c}\text { Rock body beside the right } \\
\text { Buddha }\end{array}$ & $\mathrm{Ca}$ & $\mathrm{Pb}$ & & $\mathrm{Fe}$ & $\mathrm{Ti}$ & & & \\
\hline 82 & & $\begin{array}{l}\text { Red paint on the right } \\
\text { shoulder of middle Buddha }\end{array}$ & $\mathrm{Hg}$ & $\mathrm{Pb}$ & & $\mathrm{Ca}$ & $\mathrm{Fe}$ & $\mathrm{Ti}$ & $\mathrm{S}$ & $\mathrm{Si}$ \\
\hline
\end{tabular}


Table A1. Cont.

\begin{tabular}{|c|c|c|c|c|c|c|c|c|c|c|}
\hline \multirow{2}{*}{$\begin{array}{c}\text { Test Number } \\
83\end{array}$} & \multirow[t]{2}{*}{$\begin{array}{l}\text { Statue } \\
\text { Number }\end{array}$} & Area Investigated & \multicolumn{3}{|c|}{ Major Elements } & \multicolumn{5}{|c|}{ Trace Elements } \\
\hline & & $\begin{array}{l}\text { White collar of middle } \\
\text { Buddha }\end{array}$ & $\mathrm{Ca}$ & $\mathrm{Pb}$ & $\mathrm{Hg}$ & $\mathrm{Fe}$ & $\mathrm{Ti}$ & & & \\
\hline 84 & & $\begin{array}{l}\text { White spot on the chest of } \\
\text { middle Buddha }\end{array}$ & $\mathrm{Hg}$ & $\mathrm{Pb}$ & & $\mathrm{Ca}$ & $\mathrm{Fe}$ & $\mathrm{Ti}$ & $S$ & $\mathrm{Si}$ \\
\hline 85 & & $\begin{array}{l}\text { Ring decoration of the } \\
\text { middle Buddha }\end{array}$ & $\mathrm{Ca}$ & & & $\mathrm{Fe}$ & $\mathrm{Ti}$ & & & \\
\hline 86 & & White paint on base & $\mathrm{Pb}$ & & & $\mathrm{Ca}$ & $\mathrm{Fe}$ & $\mathrm{Ti}$ & & \\
\hline 87 & & Right foot of right Buddha & $\mathrm{Pb}$ & & & $\mathrm{Ca}$ & $\mathrm{Fe}$ & $\mathrm{Ti}$ & & \\
\hline 88 & & $\begin{array}{c}\text { Gold on the chest of middle } \\
\text { Buddha }\end{array}$ & $\mathrm{Ca}$ & $\mathrm{Au}$ & & $\mathrm{Pb}$ & $\mathrm{Fe}$ & $\mathrm{Ti}$ & & \\
\hline 89 & & $\begin{array}{l}\text { Red Petal between right and } \\
\text { middle Buddha }\end{array}$ & $\mathrm{Hg}$ & $\mathrm{Pb}$ & & $\mathrm{Ca}$ & $\mathrm{Fe}$ & $\mathrm{Ti}$ & $\mathrm{S}$ & \\
\hline 90 & & $\begin{array}{l}\text { Gold on the right side of } \\
\text { middle Buddha }\end{array}$ & $\mathrm{Ca}$ & $\mathrm{Au}$ & & $\mathrm{Fe}$ & $\mathrm{Ti}$ & & & \\
\hline 92 & & $\begin{array}{l}\text { Left side of middle Buddha's } \\
\text { bun }\end{array}$ & $\mathrm{Ca}$ & & & $\mathrm{Fe}$ & $\mathrm{Ti}$ & $\mathrm{Pb}$ & & \\
\hline 93 & & Rock body of right side & $\mathrm{Pb}$ & & & $\mathrm{Ca}$ & $\mathrm{Fe}$ & $\mathrm{Ti}$ & & \\
\hline 94 & & $\begin{array}{l}\text { White paint under the right } \\
\text { Buddha's neck }\end{array}$ & $\mathrm{Pb}$ & & & $\mathrm{Ca}$ & $\mathrm{Fe}$ & $\mathrm{Ti}$ & & \\
\hline 95 & & $\begin{array}{l}\text { Left side of the right } \\
\text { Buddha-Paint shedding }\end{array}$ & $\mathrm{Pb}$ & $\mathrm{Ca}$ & & & $\mathrm{Fe}$ & $\mathrm{Cu}$ & $\mathrm{Ti}$ & \\
\hline 96 & & $\begin{array}{l}\text { Middle Buddha right } \\
\text { garment edge-rock body }\end{array}$ & $\mathrm{Pb}$ & $\mathrm{Ca}$ & & $\mathrm{Fe}$ & $\mathrm{Ti}$ & & & \\
\hline 97 & & $\begin{array}{l}\text { Blue paint on the left sleeve } \\
\text { edge of Middle Buddha }\end{array}$ & $\mathrm{Ca}$ & & & $\mathrm{Fe}$ & $\mathrm{Ti}$ & $\mathrm{Pb}$ & & \\
\hline
\end{tabular}




\section{References}

1. Xia, M. A wonderful work of Buddhist Art: The site of Longxing Temple and Buddhist statues in hoard in Qingzhou. Forum Dev. 1998, 7, 62-63.

2. Xia, M.; Yang, H.; Liu, H. Clearing up of a storage pit of Buddhist icons in the Longxing Temple at Qingzhou, Shandong. Cult. Relics 1998, 2, 3-5.

3. Brinker, H.; Nickel, L.; Zong, Z.; Bai, S. Return of the Buddha: The Qingzhou Discoveries; Royal Academy of Arts: London, UK, 2002.

4. Liu, F. Discussion on the artistic style of stone Buddha statues in late Northern Dynasties in Qingzhou area. J. Shandong Univ. (Philos. Soc. Sci.) 1998, 3, 115-120.

5. Liu, F. Buddhist stone statues of the late Northern Dynasties in the Qingzhou area, Shandong, and "Qingzhou style". Acta Archaeol. Sin. 2002, 1, 39-58.

6. Xia, M.; Ji, H. Research on crafts of colored drawing and gilding on Buddhist images in Longxing Temple. J. Weifang Eng. Vocat. Coll. 2001, 14, 53-55.

7. Su, B. Some Remarks on the City of Qingzhou-Qingzhou city Longxing Temple (1). Cult. Relics 1999, 8, 47-56.

8. Su, B. Evolution of the Longxing Temple-Qingzhou city Longxing Temple (2). Cult. Relics 1999, 9, 37-42.

9. $\mathrm{Su}, \mathrm{B}$. Some Problems Concerning the Buddhist Statues Unearthed from the Longxing Temple at Qingzhou-Qingzhou city Longxing Temple (3). Cult. Relics 1999, 10, 44-59.

10. Liu, F. Buddhist Iconic Art of the Northern Dynasties in the Shandong Region. Acta Archaeol. Sin. 1993, 3, 281-309.

11. Yang, H. Some Archaeological Thoughts on Qingzhou Area during the Northern and Southern Dynasties Period. Cult. Relics 1998, 2, 46-53.

12. Luo, S. Statues of Qingzhou in Northern Qi Dynasty and their styles. Art Res. 2000, 3, 47-52.

13. Xia, M.; Wang, R. Study On the Stone Statues of Back Screen Buddhism Unearthed in Longxing Temple, Qingzhou. Cult. Relics 2000, 5, 50-61.

14. Xia, M. Artistic Features of Buddhist statues Unearthed from Longxing Temple in Qingzhou. J. Natl. Mus. China 2000, 1, 97-103.

15. Jin, W. Artistic achievements of Buddhist statues in Qingzhou. Art Mag. 2002, 12, 50-55.

16. Huang, C. The style of Qingzhou Buddha Images and Indian Kato Art. Sculpture 2003, 1, 39-43.

17. Wang, R. Study on the origin of tower shape on Buddhist statues unearthed at Longxing Temple site. J. Weifang Eng. Vocat. Coll. 2002, 1, 61-62.

18. Fei, Y. Origin and Development of the Statue of "Qingzhou Pattern". Southeast Cult. 2000, 3, 97-102.

19. Zhou, L.; Gao, S. Study on the pattern of painted Buddha clothes of the single statue in the Northern Dynasty unearthed from Longxing Temple. Qingzhou Collect. 2019, 12, 51-58.

20. Osticioli, I.; Mendes, N.F.C.; Nevin, A.; Gil, F.P.; Becucci, M.; Castellucci, E. Analysis of natural and artificial ultramarine blue pigments using laser induced breakdown and pulsed Raman spectroscopy, statistical analysis and light microscopy. Spectrochim. Acta A 2009, 73, 525-531. [CrossRef]

21. Li, Q.; Yang, Z.; Gao, S.; Zhou, L.; Wei, S.; Ma, Q. Study on stone and the cinnabar pigment of Buddha statues of Northern Qi dynasty at Longxing Temple in Qingzhou, Shandong. Sci. Conserv. Archaeol. 2017, 29, 55-62.

22. Li, Q.; Zhou, L.; Wei, S.; Ma, Q. Study on the materials of paintings on the head of Buddha statue excavated from Longxing Temple in Qingzhou, Shandong, China. Museum 2017, 2, 28-37.

23. Zhou, L.; Gao, S.; Li, Q.; Wei, S.; Ma, Q. The color reconstruction of Buddhist statues unearthed at Longxing Temple site in Qingzhou, Shandong Province: A case of the Buddha statue No.23 of Northern Qi dynasty. China Cult. Herit. Sci. Res. 2016, 4, $46-50$.

24. Tao, L.; Wei, Q. Touched by the Past? Re-Articulating the Longxing Temple Sites as Community Heritage at Qingzhou County, China. Archaeologies 2021, 1-18. [CrossRef]

25. Liang, R. Discussion on the History of Chinese Surface Treatment Technology (VIII): Traditional Surface Decoration TechnologyGilding. Plat. Finish. 1986, 1, 37-40.

26. Jiang, G. Practical Technology of Ancient Architectural Colored Drawing (IV). Tradit. Chin. Archit. Gard. 1987, 1, 33-35.

27. Zhao, J.; Su, B.; Yu, Z.; Tan, X.; Shan, Z. Analysis of the Gilding Techniques of Painted Sculpture in Zishou Temple by using Pyrolysis-Gas Chromatography/Mass Spectrum. J. Northwest Norm. Univ. (Nat. Sci.) 2019, 55, 72-78.

28. Wei, S.Y.; Pintus, V.; Schreiner, M.A. Comparison Study of Alkyd Resin Used in Art Work by Py-GC/MS and GC/MS: The influence of aging. J. Anal. Appl. Pyrolysis 2013, 104, 441-447. [CrossRef]

29. Shuya, W.; Qinglin, M.; Schreiner, M. The Identification of Binding Media Used in the Polychromy of Western Han Dynasty Terracotta Army from Qingzhou. Relics Museol. 2009, 6, 71-78. 